\title{
Boyutlandırılmış Beş Faktör Kişilik Envanteri'nin (B5FKE) Türkçeye Uyarlanması: Üniversite Öğrencileri Örnekleminde Geçerlik ve Güvenirlik Çalışması
}

\author{
Adaptation of Faceted Inventory of the Five-Factor Model (FI-FFM) to \\ Turkish Language: A Validity and Reliability Study Amongst College Students
}

\section{Meryem Berrin BULUT ${ }^{*}$ Murat YILDIZ ${ }^{* *}$}

Öz: Kişilik, bir bireyin kim olduğunu belirten, sosyal ortamlardaki davranışlarını şekillendiren ve diğer bireylere karşı davranışlarını etkileyen bir kavram olarak düşünülebilir. Bu çalışma kapsamında Faceted Inventory of the Five-Factor Model adlı envanterin Türkçeye uyarlanması amaçlanmıştır. Çalışmaya hem devlet üniversitesi hem de özel üniversitenin farklı fakültelerinde ve yüksekokullarında öğrenim gören öğrenciler dahil edilmiştir. Bu çalışmada üç farklı katılımcı grubu bulunmaktadır. İlki 1099; ikincisi 771 ve üçüncüsü ise 48 üniversite öğrencisinden oluşmaktadır. Çalışmada veri toplama araçları olarak Watson, Nus ve Wu (2017) tarafindan geliştirilen Faceted Inventory of the Five-Factor Model'in Türkçeye uyarlanmış formu ile birlikte, Sümer ve Sümer (2005) tarafindan uyarlanan Beş Faktör Kişilik Ölçeği ve araştırmacılar tarafından geliştirilen kişisel bilgi formu kullanılmıştır. Araştırmada nicel analiz teknikleri kullanılmıştır. Açımlayıcı ve Doğrulayıcı Faktör analizlerinin yanı sıra korelasyon analizi uygulanmış ve betimsel istatistik tekniklerinden ortalama - standart sapma değerleri hesaplanmıştır. Analizler sonrasında bu ölçeğin geçerli ve güvenilir bir ölçme aracı olarak ülkemizde kullanılabileceği sonucuna ulaşılmıştır. Bulgular ilgili alanyazın temelinde tartışılmış ve bazı önerilerde bulunulmuştur.

Anahtar sözcükler: Beş Faktör, Kişilik, Geçerlik, Güvenirlik, Boyutlandırılmış Kişilik

Abstract: Personality can be thought of as a concept that indicates who an individual is, that shapes his/her behavior in the social environment and that affects his/her behavior towards other individuals. In this study, the aim is to adapt the Faceted Inventory of the Five-Factor Model to the Turkish language. Students attending different faculties and colleges of both state and private universities have been included in this study. There are three different groups of participants in this study. The first comprised 1099, the second 771 and the third 48 college students. As data collection tools, the Faceted Inventory of the Five-Factor Model developed by Watson, Nus \& Wu (2017), the Five Factor Personality Scale adapted by Sümer \& Sümer (2005) and the personal information form developed by the researchers were used. Quantitative analyses techniques were employed in this study. In addition to Exploratory and Confirmatory Factor analyses, correlation analyses was applied and means - standard deviations from descriptive statistics techniques were applied. As a result of the analyses, it was decided that this scale can be used in our country as a valid and reliable measurement tool. The findings are discussed on the basis of the relevant literature and some suggestions were made.

Keywords: Five Factor, Personality, Validity, Reliability, Faceted Personality

\footnotetext{
* Arş. Gör. Dr., Kırşehir Ahi Evran Üniversitesi, Fen-Edebiyat Fakültesi, Psikoloji Bölümü, Kurşehir. berrin_teke@yahoo.com

Prof. Dr., Sivas Cumhuriyet Üniversitesi, Edebiyat Fakültesi, Sosyal Hizmet Bölümü, Sivas. muratyildiz_my@yahoo.com

Bu çalışma 1. Uluslararası GAP Sosyal Bilimler Kongresi'nde sözel bildiri olarak sunulmuştur (4-6 Mayıs 2018, Şanlıurfa).
} 
Bireyin kim olduğunu belirten, diğer insanlarla ilişkilerini şekillendiren ve en önemlisi hayatına yön veren kişilik her bir bireyi kendine has kılmaktadır. Alanyazın incelendiğinde kişilik kavramının pek çok araştırmacı tarafından farklı şekillerde tanımlandığı görülmektedir. Örneğin kişilik, bireylerin kendilerine özgü olmalarını sağlayan ve onları diğerlerinden ayıran özellikleri içeren (McGraw-Hill-Education 2016, 258) tutarlı davranış kalıplarıdır (Burger 2006, 23). Feist ve Feist (2009) kişiliği bireyin davranışlarına hem tutarlılık hem de bireysellik kazandıran nispeten kalıcı ve benzersiz özelliklerin bir modeli olarak tanımlamışlardır. Bireyler düşünce, duygu ve davranışlarında birbirlerinden farklılaşmaktadır ve bu farklılıklar bireyin kişilik özelliklerini oluşturmaktadır (Specht et al. 2014).

Kişilik özelliklerinin ölçülmesi önemli bir problem alanıdır ve bu yönde eskiden beri çabalar sürmektedir. Farklı kuramsal çerçevelere dayalı olarak farklı kişilik ölçekleri geliştirilmiş ve son dönemde de Beş Faktör Kişilik Modeli yaygın bir biçimde kullanılmaktadır. Bununla birlikte bu model çerçevesinde yeni arayışlar da devam etmektedir. Devam eden bu süreçte Beş Faktör Kişilik Modeli kendi içinde boyutlandırılmış bir modele evrilmiştir. Diğer bir ifade ile faktörler kendi içlerinde boyutlardan oluşacak şekilde yeniden incelenmiştir. İşte sözü edilen bu perspektif kapsamında bu çalışmada, Watson, Nus ve Wu (2017) tarafindan geliştirilen "Faceted Inventory of the Five-Factor Model" adlı envanterin Türkçeye uyarlanması, geçerlik ve güvenirlik analizlerinin yapılması amaçlanmaktadır.

Yukarıda belirtildiği gibi, son zamanlarda kişiliği ölçmek amacıyla sıklıkla kullanılan ölçme araçlarında öne çıkan paradigma Beş Faktör Kişilik Modeli'dir. Yapılan incelemeler ve değerlendirmeler sonucunda, McCrae ve Costa (1987) beş faktör kişilik modelinin araştırmalarda bir ölçüm aracı olarak kullanılabileceğini ileri sürmüşlerdir. Beş faktör kişilik modeli, bireyler arasında değişkenlik gösteren tutarlı bilişsel, duygusal ve davranışsal kalıplarla ilişkili kişilik özelliklerinin yapısının hiyerarşik bir modeli olarak tanımlanmaktadır (Costa \& Widiger 2002). Bu model: Duygusal dengesizlik (N), Dışadönüklük (E), Uyumluluk (A), Sorumluluk (C) ve Deneyime Açıklık $(\mathrm{O})$ faktörlerinden oluşmaktadır. " $N$ ” duygusal dengesizliği ifade eder. Kaygılı, kendine acıyan, gergin, alıngan, kararsız ve tedirgin gibi sıfatlarla nitelendirilir. " $E$ " sosyallik, baskınlık ve hareketlilik özelliklerini içerir. Eğlenceli, sevecen, duyarlı, arkadaşça ve konuşkan gibi sıfatlarla nitelendirilir. Etkin, iddialı, enerjik, coşkulu ve dışadönük gibi sıfatlarla da tanımlanabilir. " $A$ ” iş birliği, empati, nezaket, cömertlik ve esneklik özelliklerini içerir. Minnettar, affedici, eli açık, kibar, sempatik ve güvenilir gibi sıfatlarla tanımlanır. " $C$ " hedefe yönelik davranışlarla ilişkilidir. Bu faktörde yüksek puan alan bireyler, bir işi zamanında yapmaya, düzenli ve derli toplu olmaya özen gösterirler. Verimli, düzenli, planlı, sorumlu ve dikkatli gibi s1fatlarla tanımlanır. "O” merakl1, hayal gücü kuvvetli, orijinal, yaratıcı ve çeşitliliği tercih eden gibi sıfatlarla nitelendirilir. Ayrıca, sanatçı ruhuna sahip, anlayışlı ve birçok şeye ilgi duyan gibi sifatlarla tanımlanabilir (Goldberg et al. 1990; McCrae \& Costa 1987; McCrae \& John, 1992).

Ülkemizde kişiliği ölçmek amacıyla kullanılan pek çok ölçüm aracı bulunmaktadır. Örneğin; Özgüven (1992) tarafından geliştirilen Hacettepe Kişilik Envanteri, Savran (1993) tarafindan uyarlanan Sıfat Listesi Kişilik Testi, Karancı, Dirik ve Yorulmaz (2007) tarafindan uyarlanan Eysenck Kişilik Anketi, Wasti, Lee, Ashton ve Somer (2008) tarafindan uyarlanan HEXACO, Bacanl1, İlhan ve Aslan (2009) tarafından geliştirilen Slfatlara Dayalı Kişilik Testi, Atak (2013) tarafından uyarlanan On Maddeli Kişilik Ölçeği, Savaşır (1978) tarafından uyarlanan Minnesota Çok Yönlü Kişilik Envanteri (MMPI), Demirgöz-Bal ve Hotun-Şahin (2011) tarafından uyarlanan Cervantes Kişilik Ölçeği, Subaş ve Çetin (2017) tarafından geliştirilen Enneagram Kişilik Ölçeği ve Konuk (1996) tarafından uyarlanan 16PF Kişilik Envanteri; ayrıca Beş Faktör Kişilik Modeli çerçevesinde geliştirilen/uyarlanan ölçekler olarak da Somer, Kork- 
maz ve Tatar (2000; 2004) tarafından geliştirilen Beş Faktör Kişilik Envanteri, Sümer ve Sümer (2005) tarafindan uyarlanan Beş Faktör Kişilik Özellikleri Ölçeği, Karaman, Dogan ve Coban (2010) tarafindan uyarlanan Beş Faktörlü Kişilik Envanteri, Tatar (2016) tarafından geliştirilen Beş Faktör Kişilik Ölçeğinin Kısa Formu, Horzum, Ayas ve Padır (2017) tarafindan uyarlanan Beş Faktör Kişilik Ölçeği, Morsünbül (2014) tarafından uyarlanan Hızlı Büyük Beşli Kişilik Testi ve Tatar (2017) tarafından uyarlanan Büyük Beş-50 Kişilik Testi bunlardan bazılarıdır.

Ülkemizde kullanılan kişilik ölçüm araçlarının hem ölçek uyarlama hem de ölçek geliştirme çalışmaları sonucunda oluşturulduğu görülmektedir. Boyutlandırılmış Beş Faktör Kişilik Envanteri'nin (B5FKE) yukarıda sıralanan pek çok envanterden farkı kişilik özelliklerini faktör ve faktörleri de boyutlar bazında incelemesidir. Diğer bir ifade ile beş faktöre ek olarak her bir faktör kendi içinde boyutlardan oluşmaktadır. Bu yönüyle bu envanterin kişilik hakkında derinlemesine bilgi sahibi olmamıza yardımcı olabileceği düşünülmektedir. Bu psikometrik çalışma ile ölçekler listesine bir kişilik ölçeği daha eklemenin ötesinde kişiliği, benzer ölçeklerden daha ayrıntılı ve daha derinlemesine ölçen bir ölçme aracının Türkçe alanyazına kazandırılması amaçlanmaktadır. Yukarıda belirtildiği gibi B5FKE ile kişilik özellikleri hem faktör hem de boyut bazında incelenmektedir. Her ne kadar HEXACO adlı kişilik ölçeğinin, B5FKE'ye benzer şekilde kişiliği ölçtüğü belirtilse de Ulu ve Bulut (2017) araştırmalarında bu ölçeğin geçerlik ve güvenirlik çalışmalarının tekrardan yapılmasını önermişlerdir.

$\mathrm{Bu}$ çalı̧̧mada uyarlanan B5FKE, kişiliğin kapsamlı ve boyutlandırılmış bir ölçümüdür. N, E ve $\mathrm{C}$ faktörleri beş boyut; A faktörü dört boyut ve $\mathrm{O}$ faktörü üç boyut içermektedir (bkz. Figür 1). Watson ve diğerlerine (2017) göre B5FKE'nin diğer kişilik ölçüm araçlarından farkları şu şekildedir. İlk olarak, B5FKE mevcut ölçeklerden farklı boyutları içermektedir. Örneğin, mevcut ölçeklerin N faktörü "Bedensel Şikayetler" ve "Kıskançlık” boyutlarını içermez. İkinci olarak, ölçek kişiliğin boyutlarını detaylı bir şekilde açıklığa kavuşturmaya yardımcı olur. Üçüncü olarak, kişiliğin boyut bazında incelenmesi değerli bilgiler ortaya koyarak kişilik alanyazınına katkı sağlar. Bu çalışmada uyarlanan B5FKE'nin şematik olarak gösterimi Figür 1'de verilmektedir.

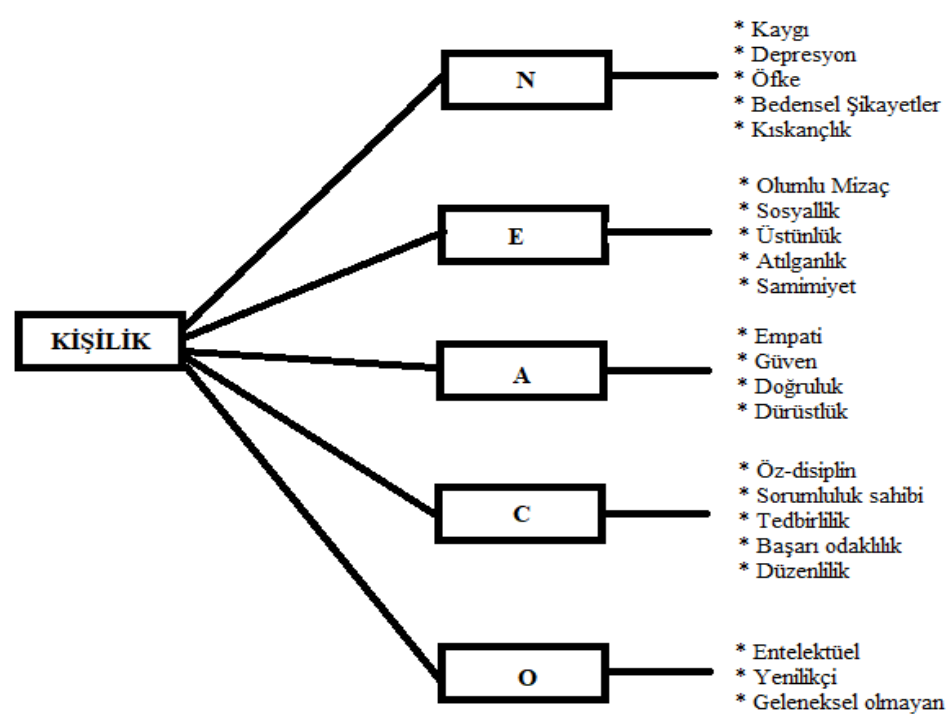

Fig. 1. B5FKE’nin Faktörleri ve Boyutları 


\section{Yöntem}

\section{Katılımcilar}

Çalışmanın üç farklı katılımcı grubu bulunmaktadır. Örnekleme yöntemi olarak basit tesadüfi olmayan örnekleme yöntemlerinden kolayda örnekleme tekniği kullanılmıştır.

Temel analizlerin ve açımlayıcı faktör analizinin yapıldığı katılımcılar devlet üniversitesi ve özel üniversitenin farklı bölümlerinde öğrenim gören öğrencilerden oluşmaktadır. Çalışmaya 1099 öğrenci gönüllü olarak katılmıştır. Katılımcıların 297'si (\%27.17) erkek ve 796'sı (\%72.83) kadınlardan oluşmaktadır. 6 kişi cinsiyetini belirtmemiştir. Katılımcıların yaş ortalaması 20.76, standart sapma değeri 1.97 ve yaş aralığı 18-37'dir. Kadın ve erkek sayılarındaki farklılık uygulama yapılan üniversitelerdeki (bölümlerdeki) kadın - erkek dağılımını yansıtmaktadır. Bunun yanı sıra, kadınlar ölçek doldurmaya erkeklere nazaran daha istekli olmaktadırlar. Bu nedenle, araştırmacılar manipülasyonla kadın - erkek sayılarını eşitlemek yerine araştırma evrenini temsil edebilecek bir dağılımı tercih etmişlerdir.

Doğrulayıcı faktör analizinin yapıldığı katılımcılar aynı devlet üniversitesi ve özel üniversitenin farklı bölümlerinde öğrenim gören öğrencilerden oluşmaktadır. Çalışmaya 771 öğrenci gönüllü olarak katılmıştır. Katılımcıların 186's1 (\%24.10) erkek ve 585’i (\%75.90) kadınlardan oluşmaktadır. Katılımcıların yaş ortalaması 20.69, standart sapma değeri 1.93 ve yaş aralığı 1837'dir.

Sümer ve Sümer (2005) tarafından uyarlanan Beş Faktör Kişilik Özellikleri ölçeği ile B5FKE arasındaki korelasyonu incelemek amacıyla veri toplanan diğer katılımcı grubunu, 17'si (\%35.40) erkek ve 31'i (\%64.60) kadın olmak üzere 48 üniversite öğrencisi oluşturmaktadır. Katılımcıların yaş ortalaması 21.60 , standart sapması 2.72 ve yaş aralığ ise $18-34$ 'tür.

\section{Veri Toplama Araçları}

Bu çalışmada verileri toplamak amacıyla B5FKE, Beş Faktör Kişilik Özellikleri Ölçeği ve Kişisel Bilgi Formu kullanılmıştır.

Boyutlandırılmış Beş Faktör Kişilik Envanteri (B5FKE) (Faceted Inventory of the Five-Factor Model): Ölçek, Watson ve diğerleri (2017) tarafindan geliştirilmiştir. Ölçekte 207 madde bulunmaktadır. Faktörlerin ve boyutların madde sayısı sırasıyla: Duygusal Dengesizlik 48 (Kayg1-10, Depresyon-10, Öfke-10, Bedensel Şikayetler-8, Kıskançlık-10); Dışadönüklük 41 (Olumlu Mizaç-8, Sosyallik-9, Üstünlük-8, Atılganlık-8, Samimiyet-8); Uyumluluk - 42 (Empati-10, Güven-11, Doğruluk-11, Alçakgönüllülük-10); Sorumluluk - 42 (Özdisiplin-8, Sorumluluk Sahibi-10, Tedbirlilik-9, Başarı Odaklılık-7, Düzenlilik-8) ve Deneyime Açıklık 34 (Entelektüel-11, Yenilikçi-11, Geleneksel Olmayan-12) şeklindedir. Ölçeğin derecelendirilmesi 5'li Likert tipi bir skala ile yapılmış olup her bir maddenin puanlanması (1) kesinlikle katılmiyorum, (2) katılmiyorum, (3) ne katıllyorum ne de katılmiyorum, (4) katıliyorum ve (5) kesinlikle katıllyorum şeklindedir. Watson ve diğ. (2017) tarafından gerçekleştirilen çalışmada ölçeğin iç tutarlılık katsayıları .64 ile .82 arasında değişmektedir. Ölçek, faktörler ve boyutlar bazında puanlanabilmekte ve puanlamada toplam puanlar dikkate alınmaktadır. Diğer bir deyişle, örneğin Duygusal Dengesizlik faktörünün hem toplam puanı değerlendirilebilmekte hem de boyutlarının (Kaygı, Depresyon, Öfke, Bedensel Şikayetler ve Kıskançlık) ayrı ayrı toplam puanları incelenebilmektedir.

Beş Faktör Kişilik Özellikleri Ölçeği: Bu ölçek, Benet-Martinez ve John (1998) tarafindan geliştirilmiş, Sümer ve Sümer (2005) tarafından Türkçeye uyarlanmıştır. Ölçekte beş faktör bulunmaktadır. Bunlar: duygusal dengesizlik (8 madde), dışadönüklük (8 madde), deneyime açılık (10 madde), uyumluluk (9 madde) ve sorumluluk ( 9 madde) şeklinde sıralanabilir. Ölçek 44 
maddeden oluşmaktadır. Ölçeğin derecelendirilmesi 5'li Likert tipi bir skala ile yapılmış olup her bir maddenin puanlanmas1 (1) kesinlikle katılmıyorum, (2) katılmıyorum, (3) ne katıliyorum ne de katılmıyorum, (4) katıliyorum ve (5) kesinlikle katıllyorum şeklindedir. Sümer ve Sümer (2005) tarafından gerçekleştirilen çalışmada bu ölçeğin iç tutarlılık katsayıları .64 ile .77 arasında değişmektedir.

Kişisel Bilgi Formu: Katılımcıların yaş, cinsiyet gibi demografik özellikleri hakkında bilgi sahibi olmak amacıyla araştırmacılar tarafından geliştirilen bir form kullanılmıştır.

\section{İşlem}

"Faceted Inventory of the Five-Factor Model" in Türkçeye uyarlama, geçerlik ve güvenirlik çalışmaları için gerekli olan izinler e-posta aracılığıyla David Watson'dan alınmıştır. Ölçek İngilizce alanında yeterliliği olan üç uzman tarafından birbirlerinden bağımsız bir şekilde Türkçeye tercüme edilmiştir. Bu tercümeler sonucunda araştırmacılar ölçeğin maddelerini düzenlemiş ve ölçek değerlendirilmek üzere üç Türk Dili uzmanına gönderilmiştir. Uzmanlardan her bir maddeyi dilbilgisi ve anlaşılabilirlik açılarından Türk diline uygunluklarını "Uygun", "Kısmen Uygun" veya "Uygun Değil" seçeneklerinden biri ile belirtmeleri istenmiştir. Son olarak ölçekler alana uygunluklarının değerlendirilmesi amacıyla üç alan uzmanına sunulmuştur. Alan uzmanlarından da ölçekteki maddeleri "Uygun”, “Kısmen Uygun” veya "Uygun Değil” seçeneklerinden biri ile belirtmeleri istenmiştir. Alan uzmanlarının önerileri sonrasında ölçeğe son şekli verilmiştir. Uyarlama çalışması sürecinde back translation (geri çeviri) yöntemi, ölçek maddelerinde fazla sayıda deyim/atasözü olduğu için kullanılmamıştır.

İlk ve ikinci katılımcı grubuna ölçekler kağıt-kalem yöntemi ile üçüncü katılımcı grubuna ise internet erişimi yoluyla uygulanmıştır. Katılımeı grubuna öncelikle araştırmanın amacı hakkında bilgi verilmiştir. Kağıt-kalem yöntemi ile uygulama yapılan gruplara ölçekler ve form ders dışı saatlerde sınıf ortamlarında uygulanmıştır. Çalışmaya katılım gönüllülük esasına göre yapılmış olup verilerin anonim bir şekilde sadece akademik çalışma kapsamında kullanılacağı konusunda katılımcılara bilgi verilmiştir. Katılımcılardan kimlik bilgileri istenmemiştir.

Verilerin analizinde SPSS 23 ve AMOS 22 programları kullanılmıştır. Veriler, Açımlayıcı Faktör Analizi, Doğrulayıcı Faktör Analizi, Cronbach Alfa iç tutarlılık katsayısı, iki yarım güvenirlik katsayısı, Pearson Momentler çarpımı korelasyon katsayısı ve betimsel istatistik tekniklerinden ortalama ve standart sapma ile analiz edilmiştir.

\section{Bulgular}

Bu kısımda ölçeğin her bir faktörü için ayrı ayrı yapılan Açımlayıcı ve Doğrulayıcı Faktör analizi, güvenirlik analizi, korelasyon analizi ve betimleyici istatistik sonuçları verilmiştir.

\section{Açımlayıcı Faktör Analizi Bulguları}

Açımlayıcı faktör analizinde faktör çıkarma yöntemi olarak temel bileşenler analizi kullanılmıştır. Temel bileşenler analizi ile çok sayıda değişkenin daha az sayıda değişken altında toplanması amaçlanır. Faktör döndürme yöntemi olarak ise varimaks kullanılmıştır. Faktör döndürme yöntemi ile bir maddenin bir faktördeki yükü artarken diğer faktörlerdeki yükü azalır (Tabachnick \& Fidell 2001). Son olarak, faktör sayısı ise özdeğere göre belirlenmiştir.

Duygusal dengesizlik: Duygusal dengesizlik faktörü için KMO değeri .897 olarak tespit edilmiştir. Leech, Barrett ve Morgan (2005) tarafindan .50-.60 “kötü”; .60-.70 “zaylf”; .70-.80 "iyi” ve .90 üzerinde "mükemmel" olarak değerlendirilmektedir. Bu değer iyi olarak değerlendirilebilir. Bartlett'in Küresellik Testi değeri 8675.75, sd: 465 ve $p=.00$ olarak tespit edilmiştir. Duygusal dengesizlik faktörü için açımlayıcı faktör analizi sonuçları Tablo 1'de verilmektedir. 
Tablo 1. Duygusal Dengesizlik Faktörü için Açımlayıcı Faktör Analizi Bulguları

\begin{tabular}{|c|c|c|c|c|c|c|c|}
\hline \multirow[b]{2}{*}{ Maddeler } & \multirow[t]{2}{*}{$\mathbf{X}$} & \multirow[t]{2}{*}{ S } & \multirow{2}{*}{$\begin{array}{c}\text { Madde } \\
\text { Silindiğinde } \\
\text { Cronbach } \alpha\end{array}$} & \multicolumn{4}{|c|}{ Faktörler } \\
\hline & & & & 1 & 2 & 3 & 4 \\
\hline madde1: Kolayca strese girerim. & 3.46 & 1.22 & .87 & .532 & & & \\
\hline $\begin{array}{l}\text { madde24: Bazen tam anlamıyla mutlu olamayaca- } \\
\text { ğımı hissederim. }\end{array}$ & 3.47 & 1.26 & .87 & .594 & & & \\
\hline madde25: İnsanlar rahat olmam gerektiğini söyler. & 3.08 & 1.24 & .87 & .567 & & & \\
\hline $\begin{array}{l}\text { madde45: Bir şeylerin kötü gitmesi ihtimaline karşı } \\
\text { sürekli endişelenirim. }\end{array}$ & 3.36 & 1.17 & .87 & .654 & & & \\
\hline madde46: Hayatı oldukça sıkıcı bulurum. & 2.81 & 1.16 & .87 & .524 & & & \\
\hline madde47: Kolayca üzülürüm. & 3.45 & 1.23 & .87 & .631 & & & \\
\hline madde67: Eleştirilere karşı aşırı hassasım. & 2.95 & 1.14 & .87 & .397 & & & \\
\hline madde68: En kötüsünü düşünmeye meyilliyim. & 3.16 & 1.30 & .87 & .617 & & & \\
\hline madde89: Çok kaygılıyım. & 3.11 & 1.25 & .87 & .686 & & & \\
\hline $\begin{array}{l}\text { madde90: Zaman zaman kendimi değersiz hissede- } \\
\text { rim. }\end{array}$ & 3.16 & 1.26 & .87 & .660 & & & \\
\hline madde91: İnsanlar karamsar olduğumu söyler. & 2.73 & 1.23 & .87 & .650 & & & \\
\hline madde111: Bazen sebepsiz yere gergin hissederim. & 3.42 & 1.14 & .87 & .514 & & & \\
\hline $\begin{array}{l}\text { madde113: Bazen dünyada yapayalnızmışım gibi } \\
\text { hissederim. }\end{array}$ & 3.13 & 1.25 & .87 & .515 & & & \\
\hline madde178: Çok sık depresyona girmem. & 2.68 & 1.18 & .87 & .428 & & & \\
\hline madde3: Kolay sinirlenirim. & 3.20 & 1.31 & .87 & & 641 & & \\
\hline madde114: Sinirimi başkalarından çıkarırım. & 2.78 & 1.20 & .87 & & .549 & & \\
\hline madde134: Çok sinirli bir insan değilim. & 2.76 & 1.19 & .87 & & .697 & & \\
\hline madde136: Kolay öfkelenirim. & 3.11 & 1.21 & .87 & & .712 & & \\
\hline madde160: Kendimi kıskanç olarak tanımlamam. & 3.11 & 1.31 & .87 & & .406 & & \\
\hline madde192: Beni sinirlendirmek zaman alır. & 3.17 & 1.22 & .87 & & .710 & & \\
\hline madde4: Çok fazla ağrım ve acım olur. & 2.31 & 1.27 & .87 & & & .579 & \\
\hline $\begin{array}{l}\text { madde48: Sanki diğer insanlardan daha çok hasta } \\
\text { olurum. }\end{array}$ & 2.57 & 1.28 & .87 & & & .604 & \\
\hline $\begin{array}{l}\text { madde70: Hazımsızlık ya da karın ağrısından sıklı- } \\
\text { kla şikayet ederim. }\end{array}$ & 2.46 & 1.30 & .87 & & & .697 & \\
\hline madde115: Mide ağrılarım sıklıkla canımı sıkar. & 2.45 & 1.30 & .87 & & & .679 & \\
\hline madde138: Çok baş ağrım olur. & 2.71 & 1.35 & .87 & & & .623 & \\
\hline $\begin{array}{l}\text { madde27: Bazen başkalarının sahip olduğu şeylere } \\
\text { sahip olmayı isterim. }\end{array}$ & 3.09 & 1.22 & .87 & & & & .552 \\
\hline $\begin{array}{l}\text { madde49: S1klıkla diğer insanların haksız bir üstün- } \\
\text { lüğe sahip olduğunu düşünürüm. }\end{array}$ & 2.74 & 1.20 & .87 & & & & .456 \\
\hline $\begin{array}{l}\text { madde71: Diğer insanların sahip oldukları şeyleri } \\
\text { genellikle kıskanırım. }\end{array}$ & 2.11 & 1.10 & .87 & & & & .689 \\
\hline madde 93: Bazen başkalarının başarılarına içerlerim. & 2.45 & 1.16 & .87 & & & & .642 \\
\hline $\begin{array}{l}\text { madde139: Başkalarının benden daha fazla şeye sa- } \\
\text { hip olduğunu görmek beni rahatsız etmez. }\end{array}$ & 2.43 & 1.14 & .87 & & & & .562 \\
\hline $\begin{array}{l}\text { madde180: Başkalarının sahip oldukları şeyleri dert } \\
\text { etmem. }\end{array}$ & 2.51 & 1.09 & .88 & & & & .515 \\
\hline
\end{tabular}

Tablo 1'de görüldüğü gibi katılımcılar maddelerden en yüksek ortalamaya 24. madde $(X=3.47)$ en düşük ortalamaya ise 71 . maddede $(X=2.11)$ sahiptir. Açımlayıcı faktör analizi sonucunda 
maddeler 4 faktör altında toplanmıştır. İlk faktörün özdeğeri 6.92 ve varyansın \%16.39'unu; ikinci faktörün özdeğeri 2.23 ve varyansın \%8.63'ünü; üçüncü faktörün özdeğeri 1.82 ve varyansın \%8.14'ünü; dördüncü faktörün özdeğeri 1.70 ve varyansın \%7.71'ini açıklamaktadır. Faktörlerin açıkladığı toplam varyans \% 40.87 'dir. Scherer, Wiebe, Luther ve Adams'a (1988) göre açıklanan varyansın \%40 - \%60 arasında olması gerekmektedir. Bu durumda bu değerin kabul edilebilir sınırlar içerisinde olduğu görülmektedir.

Açımlayıcı faktör analizi sonucunda elde edilen faktörlerin adlandırılması Tablo 2'de verilmektedir.

Tablo 2. Duygusal Dengesizlik Faktörü Boyutlarının Adlandırılması

\begin{tabular}{|c|c|c|c|c|c|}
\hline \multicolumn{3}{|c|}{ ORIGINAL SCALE } & \multicolumn{3}{|c|}{ TÜRKÇE UYARLAMA } \\
\hline Factors & Sub-factors & Items & Faktörler & Boyutlar & Maddeler \\
\hline \multirow{5}{*}{$\begin{array}{l}\mathrm{N} \\
(48 \\
\text { items) }\end{array}$} & Anxiety & $\begin{array}{l}\text { 1,23,45,67,89,111,112*,134*,1 } \\
56 *, 177^{*}\end{array}$ & \multirow{5}{*}{$\begin{array}{l}\mathrm{N} \\
\text { (31 madde) }\end{array}$} & \multirow{2}{*}{$\begin{array}{l}\text { Kayg1- } \\
\text { Depresyon }\end{array}$} & \multirow{2}{*}{$\begin{array}{l}1,24,25,45,46,47,67,68,89,9 \\
0,91,111,113,178^{*}\end{array}$} \\
\hline & Depression & $\begin{array}{l}\text { 2,24,46,68,90,113,135*,157*,1 } \\
78^{*}, 191^{*}\end{array}$ & & & \\
\hline & $\begin{array}{l}\text { Anger } \\
\text { Proneness }\end{array}$ & $\begin{array}{l}3,25,47,69,91,114,136,158 *, 17 \\
9 *, 192 *\end{array}$ & & Öfke & 3,114,134*,136,160*,192* \\
\hline & $\begin{array}{l}\text { Somatic } \\
\text { Complaints }\end{array}$ & $4,26,48,70,92,115,138,159 *$ & & $\begin{array}{l}\text { Bedensel } \\
\text { Şikayetler }\end{array}$ & $4,48,70,115,138$ \\
\hline & Envy & $\begin{array}{l}\text { 5,27,49,71,93,116,139*,160*,1 } \\
80 *, 193 *\end{array}$ & & Kiskançlık & $27,49,71,93,139 *, 180 *$ \\
\hline
\end{tabular}

Tablo 2'de görüldüğü gibi orijinal ölçek 5, uyarlama ölçek ise 4 boyuttan oluşmaktadır.

Dışadönüklük: Dışadönüklük faktörü için KMO değeri .880 ve Bartlett'in Küresellik Testi değeri 7361.99, sd: 325 ve $p=.00$ olarak tespit edilmiştir. Dışadönüklük faktörü için açımlayıcı faktör analizi sonuçları Tablo 3'te verilmektedir.

Tablo 3. Dışadönüklük Faktörü için Açımlayıcı Faktör Analizi Bulguları

\begin{tabular}{|c|c|c|c|c|c|c|c|}
\hline \multirow{2}{*}{ Maddeler } & \multirow[t]{2}{*}{$\mathbf{X}$} & \multirow[t]{2}{*}{$\mathbf{S}$} & \multirow{2}{*}{$\begin{array}{c}\text { Madde } \\
\text { Silindiğinde } \\
\text { Cronbach } \alpha\end{array}$} & \multicolumn{4}{|c|}{ Faktörler } \\
\hline & & & & 1 & 2 & 3 & 4 \\
\hline madde6: İnsanlar beni enerjik olarak tarif eder. & 3.49 & 1.15 & .86 & .629 & & & \\
\hline madde28: Genel olarak hayattan zevk alırım. & 3.58 & .98 & .86 & .496 & & & \\
\hline madde50: Hayatım heyecan vericidir. & 2.86 & 1.08 & .86 & .645 & & & \\
\hline madde72: İlginç bir hayat sürerim. & 2.58 & 1.15 & .86 & .516 & & & \\
\hline $\begin{array}{l}\text { madde94: Tanıdığım insanların çoğundan daha fazla } \\
\text { enerjiye sahibim. }\end{array}$ & 3.20 & 1.13 & .86 & .715 & & & \\
\hline madde117: Hızlı ve enerji dolu bir tempoya sahibim. & 3.35 & 1.14 & .86 & .735 & & & \\
\hline madde140: Kendimi neşeli olarak tarif edebilirim. & 3.63 & 1.03 & .86 & .624 & & & \\
\hline madde161: Diğer insanlara karşı şakacıyım. & 3.62 & .98 & .86 & .396 & & & \\
\hline $\begin{array}{l}\text { madde7: Diğer insanlarla ilişki içerisinde ola- } \\
\text { bileceğim etkinlikleri tercih ederim. }\end{array}$ & 3.57 & 1.09 & .86 & & .614 & & \\
\hline madde9: Eğlenceli toplantılara katılmayı severim. & 3.81 & 1.10 & .86 & & .674 & & \\
\hline $\begin{array}{l}\text { madde31: Hareketliliğin olduğu yerlerde bulunmayı } \\
\text { severim. }\end{array}$ & 3.54 & 1.14 & .86 & & .587 & & \\
\hline madde51: İnsanlarla vakit geçirmekten hoşlanırım. & 3.75 & .99 & .86 & & .589 & & \\
\hline madde97: Hayatımda daha çok heyecan ararım. & 3.50 & 1.10 & .86 & & .450 & & \\
\hline
\end{tabular}




\begin{tabular}{|c|c|c|c|c|c|c|}
\hline madde120: Heyecan verici deneyimlerden hoşlanırım. & 3.78 & 1.07 & .86 & .432 & & \\
\hline $\begin{array}{l}\text { madde121: Başkalarına karşı oldukça samimi ve açık } \\
\text { yürekliyim. }\end{array}$ & 3.94 & .95 & .86 & .498 & & \\
\hline $\begin{array}{l}\text { madde143: Kalabalık ve heyecan verici yerleri } \\
\text { severim. }\end{array}$ & 3.35 & 1.16 & .86 & .522 & & \\
\hline madde8: İlgi odağı olmaktan hoşlanırım. & 3.18 & 1.17 & .86 & & .645 & \\
\hline madde52: İnsanlar beni bir lider olarak tarif eder. & 2.83 & 1.12 & .86 & & .565 & \\
\hline madde53: Hız yapmaktan hoşlanırım. & 3.13 & 1.34 & .86 & & .399 & \\
\hline $\begin{array}{l}\text { madde74: Başkalarının } \\
\text { sergilemekten keyif alırım. }\end{array}$ & 3.28 & 1.12 & .86 & & .548 & \\
\hline madde142: Bir grupta lider olmaktan hoşlanmam. & 3.18 & 1.22 & .87 & & .658 & \\
\hline madde163: Çok iddialı biri değilim. & 3.17 & 1.13 & .86 & & .684 & \\
\hline $\begin{array}{l}\text { madde10: Duygu ve düşüncelerimi açıkça ifade } \\
\text { etmeye çalışırım. }\end{array}$ & 3.86 & 1.05 & .86 & & & .458 \\
\hline madde32: Bazen düşündüklerimi pat diye söylerim. & 3.58 & 1.19 & .86 & & & .740 \\
\hline $\begin{array}{l}\text { madde54: İnsanlar duymak istemese bile, ne } \\
\text { düşündüğümü söylerim. }\end{array}$ & 3.18 & 1.18 & .86 & & & .769 \\
\hline madde76: Aklımdan geçeni açıkça söylerim. & 3.53 & 1.07 & .86 & & & .760 \\
\hline
\end{tabular}

Tablo 3'te görüldüğü gibi katılımcılar maddelerden en yüksek ortalamaya 121. madde ( $\mathrm{X}=$ 3.94) en düşük ortalamaya ise 72. maddede $(X=2.58)$ sahiptir. Açımlayıcı faktör analizi sonucunda maddeler 4 faktör altında toplanmıştır. İlk faktörün özdeğeri 6.20 ve varyansın \%13.31'ini; ikinci faktörün özdeğeri 1.86 ve varyansın \%12.16'sını; üçüncü faktörün özdeğeri 1.76 ve varyansın \%9.48'ini; dördüncü faktörün özdeğeri 1.59 ve varyansın $\% 8.90$ 'ını açıklamaktadır. Faktörlerin açıkladığı toplam varyans \%43.85’tir.

Açımlayıı faktör analizi sonucunda elde edilen faktörlerin adlandırılması Tablo 4'te verilmektedir.

Tablo 4. Dışadönüklük Faktörü Boyutlarının Adlandırılması

\begin{tabular}{|c|c|c|c|c|c|}
\hline \multicolumn{3}{|c|}{ ORIGINAL SCALE } & \multicolumn{3}{|c|}{ TÜRKÇE UYARLAMA } \\
\hline Factors & Sub-factors & Items & Faktörler & Boyutlar & Maddeler \\
\hline \multirow{5}{*}{$\begin{array}{l}\mathrm{E} \\
(41 \\
\text { items })\end{array}$} & $\begin{array}{l}\text { Positive } \\
\text { Temperament }\end{array}$ & $6,28,50,72,94,117,140,161$ & \multirow{5}{*}{$\begin{array}{l}\mathrm{E} \\
(26 \\
\text { madde })\end{array}$} & $\begin{array}{l}\text { Olumlu } \\
\text { Mizaç }\end{array}$ & $6,28,50,72,94,117,140,161$ \\
\hline & Sociability & $\begin{array}{l}\text { 7,29,51,73,95*,118*,141*,16 } \\
2 *, 181^{*}\end{array}$ & & Sosyallik & 7,9,31,51,97,120,121,143 \\
\hline & Ascendance & $8,30,52,74,96,119,142 *, 163 *$ & & & \\
\hline & $\begin{array}{l}\text { Venturesome } \\
\text { ness }\end{array}$ & $9,31,53,75,97,120,143,164 *$ & & $\begin{array}{l}\text { Üstünlük- } \\
\text { At1lganlık }\end{array}$ & $8,52,53,74,142 *, 163 *$ \\
\hline & Frankness & $\begin{array}{l}\text { 10,32,54,76,98,121,144*,165 } \\
*\end{array}$ & & Samimiyet & $10,32,54,76$ \\
\hline
\end{tabular}

Tablo 4'te görüldüğü gibi orijinal ölçek 5, uyarlama ölçek ise 4 boyuttan oluşmaktadır.

Uyumluluk: Uyumluluk faktörü için KMO değeri .824 ve Bartlett'in Küresellik Testi değeri 4233.87, sd: 190 ve $p=.00$ olarak tespit edilmiştir. Uyumluluk faktörü için açımlayıcı faktör analizi sonuçları Tablo 5'te verilmektedir. 
Tablo 5. Uyumluluk Faktörü için Açımlayıcı Faktör Analizi Bulguları

\begin{tabular}{|c|c|c|c|c|c|c|}
\hline \multirow{2}{*}{ Maddeler } & \multirow[t]{2}{*}{$\mathbf{X}$} & \multirow[t]{2}{*}{$\mathbf{S}$} & \multirow{2}{*}{$\begin{array}{c}\text { Madde } \\
\text { Silindiğinde } \\
\text { Cronbach } \alpha\end{array}$} & \multicolumn{3}{|c|}{ Faktörler } \\
\hline & & & & 1 & 2 & 3 \\
\hline madde34: İnsanların çoğu iyi kalplidir. & 2.49 & 1.17 & .74 & .713 & & \\
\hline madde56: İnsanlar aslında güvenilirdir. & 2.44 & 1.08 & .74 & .769 & & \\
\hline madde78: Çoğu insan aslında dürüsttür. & 2.40 & 1.06 & .74 & .735 & & \\
\hline madde100: Genelde insanların sözlerine güvenirim. & 3.11 & 1.10 & .74 & .559 & & \\
\hline madde123: Çoğu insanın iyi niyetle hareket ettiğini düşünürüm. & 2.86 & 1.18 & .74 & .639 & & \\
\hline madde146: İnsanlara inanmakta zorlanırım. & 2.68 & 1.17 & .74 & .599 & & \\
\hline $\begin{array}{l}\text { madde167: Diğer insanlara tamamıyla güvenmek benim için } \\
\text { zordur. }\end{array}$ & 2.46 & 1.15 & .75 & .577 & & \\
\hline madde202: Çoğu kişi ilerlemek için hile yapmaya isteklidir. & 2.33 & 1.08 & .76 & .379 & & \\
\hline $\begin{array}{l}\text { madde11: Başkalarının endişelerini kendi endişelerimden } \\
\text { daha çok önemserim. }\end{array}$ & 3.06 & 1.13 & .75 & & .625 & \\
\hline madde12: İnsanlar hakkında olumlu düşünmeye gayret ederim. & 3.77 & 1.04 & .74 & & .599 & \\
\hline $\begin{array}{l}\text { madde33: Her zaman başkalarıyla işbirliği içinde olmaya } \\
\text { çalışırım. }\end{array}$ & 3.26 & 1.06 & .75 & & .466 & \\
\hline $\begin{array}{l}\text { madde55: Her zaman başkalarının ihtiyaçlarını düşünmeye } \\
\text { çalışırım. }\end{array}$ & 3.39 & 1.03 & .75 & & .658 & \\
\hline $\begin{array}{l}\text { madde77: Diğer insanların hislerini göz önünde bulun- } \\
\text { durmaya çalışırım. }\end{array}$ & 3.83 & .91 & .75 & & .583 & \\
\hline madde99: İnsanları memnun etmek için çaba harcarım. & 3.50 & 1.03 & .74 & & .640 & \\
\hline $\begin{array}{l}\text { madde122: Her zaman ihtiyacı olan insanlara yardımcı olmaya } \\
\text { çalışırım. }\end{array}$ & 4.06 & .95 & .75 & & .626 & \\
\hline madde35: Sıklıkla iğneleyici yorumlar yaparım. & 3.45 & 1.21 & .75 & & & .739 \\
\hline madde124: Biraz iğneleyici bir espri anlayışım vardır. & 2.96 & 1.26 & .76 & & & .679 \\
\hline madde147: Bazen başkalarına kaba davranırım. & 3.06 & 1.16 & .75 & & & .672 \\
\hline madde148: Bazı insanlar kibirli olduğumu düşünebilir. & 3.35 & 1.17 & .74 & & & .648 \\
\hline madde182: Bazı insanlar beni duygusuz olarak görür. & 3.33 & 1.30 & .75 & & & .486 \\
\hline
\end{tabular}

Tablo 5 'te görüldüğü gibi katılımcılar maddelerden en yüksek ortalamaya 122. madde $(X=4.06)$ en düşük ortalamaya ise 202. maddede $(X=2.33)$ sahiptir. Açımlayıcı faktör analizi sonucunda maddeler 3 faktör altında toplanmıştır. İlk faktörün özdeğeri 4.10 ve varyansın \%16.50'sini; ikinci faktörün özdeğeri 2.39 ve varyansın \%14.52'sini; üçüncü faktörün özdeğeri 2.07 ve varyansın $\% 11.73$ 'ünü açıklamaktadır. Faktörlerin açıkladığı toplam varyans \%42.75’tir.

Açımlayıcı faktör analizi sonucunda elde edilen faktörlerin adlandırılması Tablo 6'da verilmektedir.

Tablo 6. Uyumluluk Faktörü Boyutlarının Adlandırılması

\begin{tabular}{|c|c|c|c|c|c|}
\hline \multicolumn{3}{|c|}{ ORIGINAL SCALE } & \multicolumn{3}{|c|}{ TÜRKÇE UYARLAMA } \\
\hline Factors & Sub-factors & Items & Faktörler & Boyutlar & Maddeler \\
\hline \multirow{4}{*}{$\begin{array}{l}\text { A } \\
(42 \\
\text { items })\end{array}$} & Empathy & $\begin{array}{l}\text { 11,33,55,77,99,122,145*,166* } \\
\text {,182*,194* }\end{array}$ & \multirow{4}{*}{$\begin{array}{l}\text { A } \\
\text { (20 madde) }\end{array}$} & Empati & $11,12,33,55,77,99,122$ \\
\hline & Trust & $\begin{array}{l}\text { 12,34,56,78,10,123,146*,167* } \\
\text {,183*,195*,202* }\end{array}$ & & Güven & $\begin{array}{l}\text { 34,56,78,100,123,146*,167* } \\
\text {,202* }\end{array}$ \\
\hline & $\begin{array}{l}\text { Straightfor } \\
\text { wardness }\end{array}$ & $\begin{array}{l}13^{*}, 35^{*}, 57^{*}, 79^{*}, 101^{*}, 124^{*}, 1 \\
47^{*}, 168^{*}, 184^{*}, 196,203\end{array}$ & & \multirow{2}{*}{$\begin{array}{l}\text { Doğruluk- } \\
\text { Alçakgönüll } \\
\text { ülük }\end{array}$} & \multirow[t]{2}{*}{ 35*,124*,147*,148*,182* } \\
\hline & Modesty & $\begin{array}{l}\text { 14,36,58,80,102,125,148*,169 } \\
*, 185^{*}, 197 *\end{array}$ & & & \\
\hline
\end{tabular}


Tablo 6'da görüldüğü gibi orijinal ölçek 4, uyarlama ölçek ise 3 boyuttan oluşmaktadır.

Sorumluluk: Sorumluluk faktörü için KMO değeri .912 ve Bartlett'in Küresellik Testi değeri 12536.47, sd: 666 ve p= .00 olarak tespit edilmiştir. Sorumluluk faktörü için açımlayıcı faktör analizi sonuçları Tablo 7'de verilmektedir.

Tablo 7. Sorumluluk Faktörü için Açımlayıcı Faktör Analizi Bulguları

\begin{tabular}{|c|c|c|c|c|c|c|c|c|}
\hline \multirow[b]{2}{*}{ Maddeler } & \multirow[t]{2}{*}{$\mathbf{X}$} & \multirow[t]{2}{*}{$\mathbf{S}$} & \multirow{2}{*}{$\begin{array}{c}\text { Madde } \\
\text { Silindiğinde } \\
\text { Cronbach } \alpha\end{array}$} & \multicolumn{5}{|c|}{ Faktörler } \\
\hline & & & & 1 & 2 & 3 & 4 & 5 \\
\hline madde15: Yaptığım işe kolayca odaklanırım. & 3.28 & 1.09 & .91 & .595 & & & & \\
\hline madde18: Geleceğe yönelik pek çok planım vardır. & 3.92 & 1.03 & .91 & .525 & & & & \\
\hline madde19: Planlarıma dikkatlice uyarım. & 3.29 & 1.01 & .90 & .571 & & & & \\
\hline madde37: Kendimi işime çok çabuk verebilirim. & 3.35 & 1.05 & .90 & .653 & & & & \\
\hline madde40: Hedeflerime ulaşmak için çok çalışırım. & 3.69 & .97 & .90 & .544 & & & & \\
\hline $\begin{array}{l}\text { madde62: Üzerinde çalıştığım uzun vadeli birçok hede- } \\
\text { fim var. }\end{array}$ & 3.53 & 1.06 & .90 & .597 & & & & \\
\hline madde84: İnsanlar beni hırslı olarak tarif eder. & 3.01 & 1.17 & .91 & .478 & & & & \\
\hline madde81: Üzerinde çalıştığım şeye odaklanabilirim. & 3.53 & 1.02 & .90 & .579 & & & & \\
\hline madde106: Kendime yüksek hedefler belirlerim. & 3.49 & 1.10 & .91 & .534 & & & & \\
\hline madde126: Genelde işleri son dakikaya bırakırım. & 2.89 & 1.28 & .91 & & .485 & & & \\
\hline $\begin{array}{l}\text { madde128: Planlama yapmadan, içimden geldiği gibi } \\
\text { davranırım. }\end{array}$ & 2.82 & 1.21 & .91 & & .505 & & & \\
\hline madde130: İşlerimi düzene sokmakta sorun yaşarım. & 3.16 & 1.10 & .91 & & .591 & & & \\
\hline $\begin{array}{l}\text { madde149: Etrafta başkaları yokken işi savsaklama eği- } \\
\text { liminde olurum. }\end{array}$ & 3.53 & 1.18 & .90 & & .549 & & & \\
\hline $\begin{array}{l}\text { madde152: Büyük başarılara sahip olmak benim için } \\
\text { çok da önemli değil. }\end{array}$ & 3.53 & 1.14 & .91 & & .341 & & & \\
\hline madde170: İşlerden kaytarmaya çalışırım. & 3.75 & 1.12 & .90 & & .613 & & & \\
\hline madde172: Çoğunlukla düşünmeden hareket ederim. & 3.63 & 1.15 & .90 & & 606 & & & \\
\hline $\begin{array}{l}\text { madde186: Başladığım büyük projeleri genelde bitire- } \\
\text { mem. }\end{array}$ & 3.56 & 1.08 & .91 & & .545 & & & \\
\hline madde198: Sorumluluk sahibi değilim. & 3.89 & 1.13 & .90 & & .569 & & & \\
\hline madde41: Eşyaları temiz ve düzenli tutmayı severim. & 4.11 & .95 & .90 & & & .673 & & \\
\hline madde59: Çok disiplinliyim. & 3.03 & 1.15 & .90 & & & .504 & & \\
\hline madde63: Oldukça düzenliyim. & 3.46 & 1.14 & .90 & & & .776 & & \\
\hline madde85: Her şeyin yerli yerinde olmasını severim. & 3.92 & 1.01 & .90 & & & 649 & & \\
\hline madde153: İnsanlar dağınık olduğumu düşünür. & 3.46 & 1.31 & .90 & & & .684 & & \\
\hline madde173: Biraz düzensiz olabilirim. & 3.33 & 1.28 & .90 & & & .661 & & \\
\hline $\begin{array}{l}\text { madde17: Sonuca ulaşmadan önce tüm olasılıkları göz } \\
\text { önünde bulundururum. }\end{array}$ & 3.80 & .99 & .91 & & & & .635 & \\
\hline madde39: Karar vermeden önce düşünürüm. & 4.15 & .88 & .90 & & & & .628 & \\
\hline $\begin{array}{l}\text { madde61: Karar vermeden önce tüm seçenekleri } \\
\text { dikkatli bir şekilde değerlendiririm. }\end{array}$ & 3.82 & .97 & .90 & & & & .678 & \\
\hline $\begin{array}{l}\text { madde83: Bir şeyi yapmadan önce bunun sonuçlarını } \\
\text { düşünürüm. }\end{array}$ & 3.85 & .98 & .90 & & & & .674 & \\
\hline $\begin{array}{l}\text { madde105: Sonunda üzülmektense başında tedbirli ol- } \\
\text { mayı tercih ederim. }\end{array}$ & 3.82 & 1.09 & .90 & & & & .499 & \\
\hline
\end{tabular}




\begin{tabular}{|c|c|c|c|c|c|}
\hline madde107: Çok detaycıyımdır. & 3.55 & 1.16 & .91 & .366 & \\
\hline madde16: Verdiğim sözleri yerine getiririm. & 4.15 & .89 & .91 & & .537 \\
\hline $\begin{array}{l}\text { madde38: Ödünç aldığım bir şeyi her zaman geri veri- } \\
\text { rim. }\end{array}$ & 4.41 & .92 & .91 & & .501 \\
\hline madde60: Verdiğim sözleri tutarım. & 4.15 & .92 & .91 & & .527 \\
\hline $\begin{array}{l}\text { madde103: İşlerimi yaparken doğru şekilde yapmaya } \\
\text { çalışırım. }\end{array}$ & 4.08 & .87 & .90 & & .457 \\
\hline madde127: İnsanlar her zaman bana güvenebilir. & 3.96 & 1.01 & .91 & & .651 \\
\hline $\begin{array}{l}\text { madde129: Hedeflerime ulaşmak için fedakârlık yap- } \\
\text { maya hazırım. }\end{array}$ & 3.80 & .99 & .91 & & .526 \\
\hline madde150: Çok güvenilirim. & 3.82 & .96 & .91 & & .559 \\
\hline
\end{tabular}

Tablo 7'de görüldüğü gibi katılımcılar maddelerden en yüksek ortalamaya 38. madde (X=4.41) en düşük ortalamaya ise 128 . maddede $(X=2.82)$ sahiptir. Açımlayıcı faktör analizi sonucunda maddeler 5 faktör altında toplanmıştır. İlk faktörün özdeğeri 8.84 ve varyansın \%9.64'ünü; ikinci faktörün özdeğeri 2.36 ve varyansın \%9.52'sini; üçüncü faktörün özdeğeri 1.96 ve varyansın \%8.45'ini; dördüncü faktörün özdeğeri 1.69 ve varyansın \%8.43'ünü; beşinci faktörün özdeğeri 1.51 ve varyansın \%8.18'ini açıklamaktadır. Faktörlerin açıkladığı toplam varyans \%44.22'dir.

Açımlayıcı faktör analizi sonucunda elde edilen faktörlerin adlandırılması Tablo 8'de verilmektedir.

Tablo 8. Sorumluluk Faktörü Boyutlarının Adlandırılması

\begin{tabular}{|c|c|c|c|c|c|}
\hline \multicolumn{3}{|c|}{ ORIGINAL SCALE } & \multicolumn{3}{|c|}{ TÜRKÇE UYARLAMA } \\
\hline Factors & Sub-factors & Items & Faktörler & Boyutlar & Maddeler \\
\hline \multirow{5}{*}{$\begin{array}{l}\text { C } \\
(42 \\
\text { items) }\end{array}$} & $\begin{array}{l}\text { Self- } \\
\text { Discipline }\end{array}$ & $\begin{array}{l}\text { 15,37,59,81,103,126*,149*,1 } \\
70 *\end{array}$ & \multirow{5}{*}{$\begin{array}{l}\text { C } \\
\text { (37 madde) }\end{array}$} & Öz disiplin & $15,18,19,37,40,62,81,84,106$ \\
\hline & Dutifulness & $\begin{array}{l}\text { 16,38,60,82,104,127,150,171 } \\
*, 186^{*}, 198^{*}\end{array}$ & & $\begin{array}{l}\text { Sorumluluk } \\
\text { Sahibi }\end{array}$ & $16,38,60,103,127,129,150$ \\
\hline & Deliberation & $\begin{array}{l}\text { 17,39,61,83,105,128*,151*,1 } \\
72 *, 187^{*}\end{array}$ & & Tedbirlilik & $17,39,61,83,105,107$ \\
\hline & $\begin{array}{l}\text { Achievement } \\
\text { Striving }\end{array}$ & $18,40,62,84,106,129,152 *$ & & $\begin{array}{l}\text { Başarı } \\
\text { Odaklılık }\end{array}$ & $\begin{array}{l}126,128,130 *, 149 *, 152 *, 17 \\
0 *, 172,186 *, 198 *\end{array}$ \\
\hline & Order & $\begin{array}{l}\text { 19,41,63,85,107,130*,153*,1 } \\
73^{*}\end{array}$ & & Düzenlilik & $41,59,63,85,153 *, 173 *$ \\
\hline
\end{tabular}

Tablo 8'de görüldüğ̈̈ gibi hem orijinal hem de uyarlama ölçek 5 boyuttan oluşmaktadır.

Deneyime Açıklık: Deneyime açıklık faktörü için KMO değeri .815 ve Bartlett'in Küresellik Testi değeri 4527.74, sd: 136 ve $\mathrm{p}=.00$ olarak tespit edilmiştir. Deneyime açıklık faktörü için açımlayıcı faktör analizi sonuçları Tablo 9'da verilmektedir.

Tablo 9. Deneyime Açıklık Faktörü için Açımlayıcı Faktör Analizi Bulguları

\begin{tabular}{|c|c|c|c|c|c|c|}
\hline \multirow{2}{*}{ Maddeler } & \multirow[t]{2}{*}{$\mathbf{X}$} & \multirow[t]{2}{*}{ S } & \multirow{2}{*}{$\begin{array}{c}\text { Madde } \\
\text { Silindiğinde } \\
\text { Cronbach } \alpha\end{array}$} & \multicolumn{3}{|c|}{ Faktörler } \\
\hline & & & & 1 & 2 & 3 \\
\hline madde42: Yeni bir şeyler öğrenmekten hoşlanırım. & 4.25 & .85 & .73 & .685 & & \\
\hline madde43: Yeni deneyimler yaşamaktan hoşlanırım. & 4.17 & .87 & .73 & .706 & & \\
\hline madde65: Farklı yaşam tarzları ve kültürlere karşı hoşgörülüyüm. & 4.18 & .93 & .72 & .733 & & \\
\hline madde66: Özgür düşünceliyim. & 4.02 & .98 & .72 & .672 & & \\
\hline
\end{tabular}




\begin{tabular}{|c|c|c|c|c|c|c|}
\hline madde137: Alternatif bakış açılarına karşı oldukça hoşgörülüyüm. & 3.88 & .95 & .73 & .622 & & \\
\hline madde154: Başka kültürlere karşı ilgiliyim. & 3.83 & 1.01 & .72 & .503 & & \\
\hline madde175: Yeni şeyler denemeyi severim. & 3.77 & 1.05 & .73 & .533 & & \\
\hline madde20: Müze veya sanat galerilerinde vakit geçirmekten hoşlanırım. & 3.01 & 1.24 & .71 & & .754 & \\
\hline madde108: Sanatsal etkinliklere gitmekten hoşlanırım. & 3.37 & 1.19 & .70 & & .803 & \\
\hline madde131: Sanata karş1 ilgiliyim. & 3.26 & 1.23 & .70 & & .763 & \\
\hline madde188: Klasik müziği severim. & 3.01 & 1.26 & .73 & & .531 & \\
\hline madde199: Bale ya da şiir dinletisi gibi etkinliklerden sıkılırım. & 3.05 & 1.32 & .72 & & .578 & \\
\hline madde110: Değerlerimi muhafazakâr olarak nitelerim. & 2.47 & 1.10 & .74 & & & .691 \\
\hline $\begin{array}{l}\text { madde133: Hükümetimiz geleneksel değerlerimizi korumak için } \\
\text { çalışmalıdır. }\end{array}$ & 2.13 & 1.06 & .75 & & & .704 \\
\hline madde176: Özümde oldukça gelenekselim. & 2.78 & 1.08 & .74 & & & .713 \\
\hline madde190: Geleneksel aile, toplumumuz için gereklidir. & 2.34 & 1.08 & .73 & & & .727 \\
\hline $\begin{array}{l}\text { madde206: Doğru ve yanlışın birbirinden kesin çizgilerle ayrıldığına } \\
\text { inanırım. }\end{array}$ & 2.54 & 1.17 & .75 & & & .423. \\
\hline
\end{tabular}

Tablo 9'da görüldüğü gibi katılımcılar maddelerden en yüksek ortalamaya 42. madde $(X=4.25)$ en düşük ortalamaya ise 133. maddede $(X=2.13)$ sahiptir. Açımlayıcı faktör analizi sonucunda maddeler 3 faktör altında toplanmıştır. İlk faktörün özdeğeri 3.92 ve varyansın \%17.98'ini; ikinci faktörün özdeğeri 2.46 ve varyansın \%15.63'ünü; üçüncü faktörün özdeğeri 1.62 ve varyansın \%13.39'unu açıklamaktadır. Faktörlerin açıkladığı toplam varyans \%47'dir.

Açımlayıcı faktör analizi sonucunda elde edilen faktörlerin adlandırılması Tablo 10'da verilmektedir.

Tablo 10. Deneyime Açıklık Faktörü Boyutlarının Adlandırılması

\begin{tabular}{|c|c|c|c|c|c|}
\hline \multicolumn{3}{|c|}{ ORIGINAL SCALE } & \multicolumn{3}{|c|}{ TÜRKÇE UYARLAMA } \\
\hline Factors & Sub-factors & Items & Faktörler & Boyutlar & Maddeler \\
\hline \multirow{3}{*}{$\begin{array}{c}\mathrm{O} \\
\text { (34 items) }\end{array}$} & Intellectance & $\begin{array}{c}20,42,64,86,108,131,154,174,1 \\
88,199 *, 204 *\end{array}$ & \multirow{3}{*}{$\begin{array}{c}\mathrm{O} \\
(17 \text { madde })\end{array}$} & Entelektüel & 20,108,131,188,199* \\
\hline & $\begin{array}{l}\text { Novel } \\
\text { Experience } \\
\text { Seeking }\end{array}$ & $\begin{array}{c}21,43,65,87,109,132,137,175,1 \\
89 *, 200 *, 205^{*}\end{array}$ & & Yenilikçi & $42,43,65,66,137,154,175$ \\
\hline & $\begin{array}{c}\text { Nontradition- } \\
\text { alism }\end{array}$ & $\begin{array}{c}22,44,66,88,110^{*}, 133^{*}, 155^{*}, 17 \\
6^{*}, 190^{*}, 201^{*}, 206^{*}, 207^{*}\end{array}$ & & $\begin{array}{l}\text { Geleneksel } \\
\text { Olmayan }\end{array}$ & $110^{*}, 133^{*}, 176^{*}, 190 *, 206^{*}$ \\
\hline
\end{tabular}

Tablo 10'da görüldüğü gibi hem orijinal hem de uyarlama ölçek 3 boyuttan oluşmaktadır.

\section{Doğrulayıcı Faktör Analizi Bulguları}

Doğrulayıcı faktör analizinde parametre tahminleme yöntemi olarak en büyük olabilirlik (maximum likelihood) kullanılmıştır. Her bir faktör için önerilen ve kuramsal temele uyan sınırlı sayıda bazı modifikasyonlar yapılmıştır. Doğrulayıcı faktör analizi beş faktör kişilik özelliklerinin (N, E, A, C ve O) her biri için ayrı ayrı yapılmıştır. Bulgular Tablo 11'de verilmektedir.

Tablo 11. Doğrulayıcı Faktör Analizi Bulguları

\begin{tabular}{lccccccccc}
\hline Kişilik Özellikleri & $\chi \mathbf{2}$ /sd & GFI & AGFI & NFI & RFI & IFI & TLI & CFI & RMSEA \\
\hline Duygusal Dengesizlik & 2.58 & .912 & - & - & - & .908 & - & .908 & .05 \\
Dişadönüklük & 2.89 & - & - & - & - & .927 & .914 & .926 & .04 \\
Uyumluluk & 2.35 & .953 & .939 & - & - & .933 & .919 & .932 & .04 \\
\hline
\end{tabular}




\begin{tabular}{lccccccccc}
\hline Sorumluluk & 2.42 & .909 & - & - & - & .916 & .904 & .915 & .04 \\
Deneyime Açıklık & 2.16 & - & - & .941 & .912 & .968 & .951 & .967 & .04 \\
\hline
\end{tabular}

Tablo 11'de sistem tarafından hesaplanan uyum iyilik değerleri verilmektedir. Bu değerler model uyumunun kabul edilebilir düzeylerde olduğunu göstermektedir. $\chi^{2} / \mathrm{sd}$ değerinin Byrne'e (2010) göre 3'ten küçük olması iyi bir uyuma işaret etmektedir. GFI (Goodness of Fit Index, Uyum İyiliği Endeksi), AGFI (Adjusted Goodness of Fit Index, Uyarlanmış Uyum İyiliği Endeksi), NFI (Normed Fit Index, Normlu Uyum Endeksi), RFI (Relative Fit Index, Göreceli Uyum Endeksi), IFI (Incremental Fit Index, Artan uyum endeksi) ve TLI'nın (Tucker - Lewis Index, Tucker - Lewis Endeksi) aldığı .950 'den büyük değerler iyi bir uyumun göstergesi iken .900 'den büyük olan değerler ise kabul edilebilir bir uyumun göstergesidir (Schermelleh-Engel et al. 003; Tabachnick \& Fidell 2001). Tabachnick ve Fidell'e (2001) göre CFI'nın (Comparative Fit Index, Karşılaştırmalı Uyum Endeksi) .900'den yüksek olması iyi bir uyumu göstermektedir. RMSEA (Root Mean Square Error of Approximation, Ortalama Karekök Hata Terimi) değerinin .05 'ten küçük olması iyi bir uyum iyiliğini; .08'den küçük olması ise kabul edilebilir bir uyum iyiliğini göstermektedir (Thompson 2004).

\section{Ölçüt Geçerliği}

Uyarlaması yapılan B5FKE'nin daha önce ülkemizde Sümer ve Sümer (2005) tarafından geçerlik ve güvenirlik çalışması yapılan Beş Faktör Kişilik Özellikleri Ölçeği (BFKÖÖ) ile arasındaki ilişkiler Tablo 12'de verilmektedir.

Tablo 12. B5FKE ile Beş Faktör Kişilik Özellikleri Ölçeği arasındaki korelasyonlar

\begin{tabular}{|c|c|c|c|c|c|c|c|c|c|c|}
\hline & Değişkenler & 2 & 3 & 4 & 5 & 6 & 7 & 8 & 9 & 10 \\
\hline \multirow{5}{*}{ 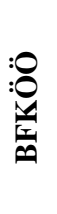 } & $1 . \mathrm{N}$ & -.09 & $-.58^{*}$ & $-.31^{*}$ & -.18 & $.81^{*}$ & .19 & -.15 & $-.29^{*}$ & -.27 \\
\hline & 2.E & 1 & -.03 & $.32^{*}$ & $.50^{*}$ & .01 & $.82^{*}$ & .01 & $.42^{*}$ & $.30^{*}$ \\
\hline & 3.A & & 1 & $.39^{*}$ & .11 & $-.67^{*}$ & -.15 & $.63^{*}$ & .24 & .12 \\
\hline & 4.C & & & 1 & $.31^{*}$ & $-.42^{*}$ & $.32^{*}$ & .24 & $.85^{*}$ & .02 \\
\hline & 5.0 & & & & 1 & -.15 & $.35^{*}$ & .08 & $.33^{*}$ & $.58^{*}$ \\
\hline \multirow{5}{*}{$\begin{array}{l}\frac{1}{1} \\
\frac{1}{10} \\
0\end{array}$} & 6.N & & & & & 1 & .17 & $-.39^{*}$ & $-.34^{*}$ & -.28 \\
\hline & 7.E & & & & & & 1 & .07 & $.40^{*}$ & .05 \\
\hline & 8.A & & & & & & & 1 & .01 & -.06 \\
\hline & 9.C & & & & & & & & 1 & .05 \\
\hline & 10.0 & & & & & & & & & 1 \\
\hline
\end{tabular}

Tablo 12'de görüldüğü gibi BFKÖÖ'nün faktörleri ile B5FKE'nin faktörleri arasında anlamlı ilişkiler tespit edilmiştir. BFKÖÖ'nün $\mathrm{N}$ faktörü ile B5FKE'nin $\mathrm{N}$ faktörü arasında .81; $\mathrm{E}$ faktörü ile E faktörü arasında .82; A faktörü ile A faktörü arasında .63; C faktörü ile C faktörü arasında .85 ve $\mathrm{O}$ faktörü ile $\mathrm{O}$ faktörü arasında .58 düzeyinde anlamlı bir ilişki bulunmaktadır. İki ölçeğin faktörlerinde en yüksek düzeyde ilişki $\mathrm{C}$ faktörleri, en düşük düzeyde ilişki ise $\mathrm{O}$ faktörleri arasındadır.

\section{Güvenirlik Değerleri}

$\mathrm{Bu}$ çalışma kapsamında Cronbach iç tutarlılık katsayısı ve iki yarım güvenirlik katsayısı incelenmiştir. Bulgular Tablo 13’te verilmektedir. 
Tablo 13. Beş Faktör Kişilik Özelliklerine ait Cronbach Alfa ( $\alpha$ ) ve İki Yarım Güvenirlik (İki Y.G.) Değerleri

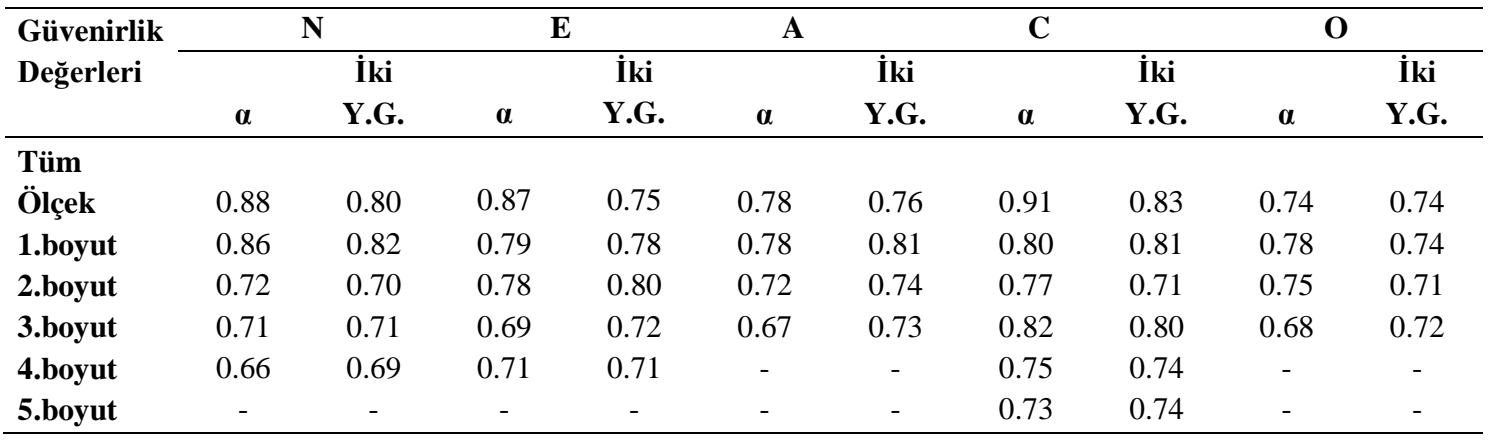

Tablo 13'te her bir faktör için güvenirlik değeri ilk satırda verilmektedir. Örneğin, N faktörü için Cronbach Alfa iç tutarlılık katsayısı 0.88 ve iki yarım güvenirlik katsayısı ise 0.80 olarak tespit edilmiştir. Tablonun ilk sütununda verilen boyutlar ise her bir faktör için farklı olarak adlandırılması nedeniyle 1. Boyut, 2. Boyut, 3. Boyut, 4. Boyut ve 5. Boyut şeklinde belirtilmiştir. N faktörünün 1. Boyutu (Kaygi-Depresyon) için Cronbach Alfa değerinin 0.86 ve iki yarım güvenirlik katsayısının 0.82 olduğu görülmektedir. Tablo 13 'te görüldüğü gibi en yüksek güvenirlik değerine $C$, en düşük değere ise O faktörü sahiptir. Özdamar (2004) ve Kayış (2005), “.60 $\leq \alpha<.80$ ” güvenirlik katsayısını oldukça güvenilir ve ". $80 \leq \alpha<1.00$ ” güvenirlik katsayısını ise yüksek derecede güvenilir olarak değerlendirmektedirler (akt. Erol 2018). Bu değerlendirmelere göre uyarlanan ölçeğin güvenirlik değerlerinin kabul edilebilir sınırlar içerisinde olduğu söylenebilir.

\section{Betimsel İstatistik Değerleri ve Korelasyonlar}

Ölçeğin boyutlarına ait ortalama ve standart sapma değerleri Tablo 14'te verilmektedir.

Tablo 14. Boyutlara Ait Betimsel İstatistik Değerleri

\begin{tabular}{lccc}
\hline \multicolumn{1}{c}{ Boyutlar } & $\mathbf{n}$ & $\mathbf{X}$ & $\mathbf{S}$ \\
\hline N1:Kayg1-Depresyon & 1099 & 3.14 & .73 \\
N2:Öfke & 1099 & 3.02 & .80 \\
N3:Bedensel Şikayetler & 1099 & 2.50 & .89 \\
N4:Kıskançlık & 1099 & 2.56 & .70 \\
\hline E1:Olumlu Mizaç & 1099 & 3.29 & .69 \\
E2:Sosyallik & 1099 & 3.65 & .67 \\
E3:Üstünlük-Atılganlık & 1099 & 3.13 & .74 \\
E4:Samimiyet & 1099 & 3.54 & .82 \\
\hline A1:Empati & 1099 & 3.55 & .61 \\
A2:Güven & 1099 & 2.60 & .69 \\
A3:Doğruluk-Alçakgönüllülük & 1099 & 3.23 & .78 \\
\hline C1:Özdisiplin & 1099 & 3.45 & .65 \\
C2:Sorumluluk Sahibi & 1099 & 4.05 & .58 \\
C3:Tedbirlilik & 1099 & 3.83 & .68 \\
C4:Başarı Odaklılık & 1099 & 3.42 & .69 \\
C5:Düzenlilik & 1099 & 3.55 & .84 \\
\hline O1:Entelektüel & 1098 & 3.14 & .88 \\
O2:Yenilikçi & 1099 & 4.01 & .62 \\
O3:Geleneksel Olmayan & 1099 & 2.45 & .73 \\
\hline
\end{tabular}

Tablo 14'te görüldüğü gibi katılımcılar $\mathrm{N}$ faktörünün boyutlarından en yüksek ortalamayı kaygldepresyon $(\mathrm{X}=3.14)$ en düşük ortalamayı ise bedensel şikayetler $(\mathrm{X}=2.50)$; E faktörünün bo- 
yutlarından en yüksek ortalamayı sosyallik $(X=3.65)$ en düşük ortalamayı ise üstünlükatılganlık $(\mathrm{X}=3.13)$; A faktörünün boyutlarından en yüksek ortalamayı empati $(\mathrm{X}=3.55)$ en düşük ortalamayı ise güven $(X=2.60)$; $C$ faktörünün boyutlarından en yüksek ortalamayı sorumluluk sahibi $(\mathrm{X}=4.05)$ en düşük ortalamayı ise başarı odaklılık $(\mathrm{X}=3.42)$ ve $\mathrm{O}$ faktörünün boyutlarından en yüksek ortalamayı yenilikçi $(X=4.01)$ en düşük ortalamayı ise geleneksel olmayan $(X=2.45)$ boyutunda almışlardır.

Tüm ölçek bazında incelendiğinde, katılımcılar en yüksek ortalamaya $C$ faktörünün sorum-

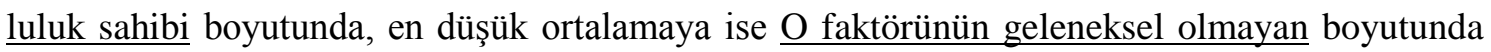
sahiptirler.

Tablo 15 'te ölçeğin faktörlerine ait betimsel istatistik değerleri ve korelasyon sonuçları verilmektedir.

Tablo 15. Faktörlere Ait Betimsel İstatistik Değerleri ve Korelasyonlar

\begin{tabular}{cccccccc}
\hline Değişkenler & $\mathbf{n}$ & $\mathbf{X}$ & $\mathbf{S}$ & $\mathbf{E}$ & $\mathbf{A}$ & $\mathbf{C}$ & $\mathbf{O}$ \\
\hline $\mathbf{N}$ & 1099 & 2.90 & .56 & $-.12^{*}$ & $-.22^{*}$ & $-.18^{*}$ & $-.11^{*}$ \\
$\mathbf{E}$ & 1099 & 3.40 & .53 & 1 & $.10^{*}$ & $.28^{*}$ & $.26^{*}$ \\
$\mathbf{A}$ & 1099 & 3.09 & .47 & & 1 & $.25^{*}$ & $.12^{*}$ \\
$\mathbf{C}$ & 1099 & 3.63 & .51 & & & 1 & $.18^{*}$ \\
$\mathbf{O}$ & 1098 & 3.30 & .48 & & & & 1 \\
\hline${ }^{*} \mathrm{p}<.05$ & & & & & & &
\end{tabular}

Tablo 15'te görüldüğ̈ gibi katılımcılar en yüksek ortalamaya $C(X=3.63)$ ve en düşük ortalamaya ise $N(X=2.90)$ faktöründe sahiptirler. Yine tabloda görüldügü gibi tüm faktörlerin birbiriyle arasında anlamlı ilişkiler tespit edilmiştir. $\mathrm{N}$ faktörü ile tüm faktörler arasında olumsuz ve anlamlı bir ilişki bulunmakta iken diğer faktörlerin birbirleri arasında olumlu ve anlamlı bir ilişki olduğu görülmektedir. Ayrıntılı bir şekilde ifade etmek gerekirse, $\mathrm{N}$ faktörü ile $\mathrm{E}$ ( $r=$ .12 , p <.05), A $(r=-.22, \mathrm{p}<.05), \mathrm{C}(r=-.18, \mathrm{p}<.05)$ ve $\mathrm{O}(r=-.11, \mathrm{p}<.05)$ faktörleri arasında olumsuz bir ilişki bulunmaktadır. E faktörü ile A $(r=.10, \mathrm{p}<.05), \mathrm{C}(r=.28, \mathrm{p}<.05)$ ve $\mathrm{O}(r=$ $.26, \mathrm{p}<.05)$ faktörleri arasında olumlu bir ilişki bulunmaktadır. A faktörü ile $\mathrm{C}(r=.25, \mathrm{p}<.05)$ ve $\mathrm{O}(r=.12, \mathrm{p}<.05)$ faktörleri arasında olumlu bir ilişki bulunmaktadır. Son olarak, C faktörü ile $\mathrm{O}$ faktörü arasında $(r=.18, \mathrm{p}<.05)$ olumlu bir ilişki bulunmaktadır.

\section{Tartışma ve Sonuç}

Psikolojinin temel konularından biri olan kişilik, bireyin kim olduğunu belirtmesi açısından büyük önem taşımaktadır. Bireylerin diğerleri ile olan ilişkilerini şekillendirerek onların yaşamlarına yön veren kişiliğin nispeten kalıcı ve bireye has olduğunu söyleyebiliriz. Bu çalışma ile Watson ve diğerleri (2017) tarafından geliştirilen Boyutlandırılmış Beş Faktör Kişilik Envanteri (Faceted Inventory of the Five-Factor Model) Türkçeye uyarlanmış, geçerlik ve güvenirlik analizleri yapılmıştır.

Açımlayıcı faktör analizi sonucunda;

$\mathrm{N}$ faktörü için orijinal ölçekte 48 madde ve 5 boyut bulunmakta iken uyarlama ölçek 31 maddeden oluşmakta ve 4 boyutta toplanmaktadır. Boyutların adlandırılması orijinal ölçektekine benzer şekilde "Kaygı-Depresyon”, "Öfke”, "Bedensel Şikayetler” ve "Kıskançlık” şeklinde yapılmıştır. Orijinal ölçekten farklı olarak "Kaygı" ve "Depresyon" boyutları uyarlama ölçekte ayrı boyutlar olarak değil de tek bir boyut altında toplanmıştır. "Kaygı-depresyon" boyutundaki maddeler, envanterin orijinaliyle karşılaştırıldığında 14 maddeden 11'inin envanterin kaygı ve depresyon boyutlarının maddeleriyle örtüştüğ̈̈ görülmektedir (bk. Tablo 1). Kayg1-depresyon boyutundaki maddeler incelendiğinde "Çok kaygıllyım" ve "Çok sık depresyona 
girmem" gibi birkaç madde depresyon ve kaygı durumlarını net bir şekilde yansıtsa da katılımcıların (üniversite öğrencileri), depresyon ve kaygıya ilişkin maddelerdeki duygu durumlarını benzer durumlar olarak algılamış olabilecekleri düşünülmektedir. Dolayısıyla söz konusu maddeler aynı alt boyutta toplanmış olabilir. Ayrıca bu boyuttaki ifadelerin klinik düzeyde tanı konmayı gerektirecek bir kaygı ve depresyon düzeyi ölçümünden ziyade sağlıklı bireylerin kaygı ve depresyona ilişkin eğilim düzeylerini ölçmeye yönelik bir yapıya sahip olması, bu ifadelerin birbirinden net bir şekilde ayrışmasını engellemiş olabilir. Örneğin, envanterin orijinalinde bir kaygı ifadesi olan "Bir şeylerin kötü gitmesi ihtimaline karşı sürekli endişelenirim" ile depresyon maddesi olan "En kötüsünü düşünmeye meyilliyim” maddeleri Türkçe versiyonunda aynı faktör altında toplanmıştır. Bu iki cümledeki ayrımı yapabilmek bireyin kendisini iyi tanımasıyla yani benlik bilincinin gerçek benliğiyle örtüşme düzeyinin artmasıyla mümkün olabilir. Bu gelişimin ise bir ömür boyu devam ettiği düşünülürse, üniversite öğrencilerinin ayrım yapabilecek düzeyde kendilerini tanımadıkları ileri sürülebilir. Dolayısıyla daha ileriki yaş gruplarıyla yapılacak psikometrik çalışmalar farklı sonuçlar sunabilir.

E faktörü için orijinal ölçekte 41 madde 5 boyut bulunmaktadır. Uyarlama ölçekte ise 4 boyut altında toplanan toplam 26 madde bulunmaktadır. Boyutların adlandırılması orijinal ölçektekine benzer şekilde "Olumlu Mizaç”, "Sosyallik”, “Üstünlük-Atılganlık” ve "Samimiyet” şeklinde yapılmıştır. Olumlu mizacın tüm maddelerinin orijinal ve uyarlama ölçekte birebir aynı olması, bu boyutun evrenselliği ve kültürden bağımsızlığı hakkında ipuçları vermektedir. Orijinal ölçekte "Venturesomeness" (atılganlık) boyutunun bazı maddelerinin $(31,97,120,143)$ uyarlama ölçekte sosyallik boyutunda toplandığı görülmektedir.

A faktörü için orijinal ölçekte 42 madde 4 boyut bulunmakta iken uyarlama ölçekte 20 maddenin 3 boyut altında öbekleştiği görülmüştür. Boyutların adlandırılması orijinal ölçektekine benzer şekilde “Empati”, “Güven” ve “Doğruluk-Alçakgönüllülük” şeklinde yapılmıştır. Orijinal ölçekteki "Modesty” (alçakgönüllülük) boyutunun bir maddesi (148) uyarlama ölçekte "Doğruluk-Alçakgönüllülük” boyutu altında toplanmışken diğer maddelerinin çalışmadığı görülmektedir.

C faktörü için orijinal ölçekte 42 olan madde sayısı uyarlama ölçekte 37'ye düşmesine karşın boyut sayısı değişmemiş, ölçek orijinalindeki gibi 5 boyuttan oluşmaktadır. Boyutların adlandırılması orijinal ölçektekine benzer şekilde "Özdisiplin”, "Sorumluluk Sahibi”, "Tedbirlilik”, "Başarı Odaklılık” ve "Düzenlilik” şeklinde yapılmıştır. Her ne kadar madde dağılımları birbirlerinden farklılaşsa da bu faktör için boyut dağılımının orijinal şeklini koruduğu görülmektedir. Bu nedenle, evrensellik ve kültürden bağımsızlık konusunda en öne çıkan faktörün C faktörü olduğu söylenebilir.

O faktörü için orijinal ölçekte 34 olan madde sayısı uyarlama ölçekte 17'ye düşmüştür. Bununla birlikte boyut sayısında bir değişiklik olmamış ve ölçek orijinalindeki gibi 3 boyuttan oluşmaktadır. Boyutların adlandırılması orijinal ölçekteki gibi "Entelektüel”, "Yenilikçi” ve "Geleneksel Olmayan” şeklinde yapılmıştır. Boyutların adlandırılması orijinal ölçekle aynı olmasına rağmen bazı maddeler orijinal ölçektekine göre farklı boyutlar altında toplanmıştır.

Doğrulayıcı faktör analizi sonuçları tüm uyum iyiliği endekslerinin kabul edilebilir sınırlar içerisinde olduğunu göstermektedir. Sonuç olarak, boyut bazında önerilen modelin doğrulandığ1 söylenebilir.

Sümer ve Sümer (2005) tarafından uyarlanan Beş Faktör Kişilik Özellikleri Ölçeği ile B5FKE arasındaki ilişkiye bakıldığında tüm faktörlerin birbirleri ile arasında anlamlı düzeyde korelasyon olduğu N, E ve C faktörleri için korelasyonların kuvvetli olduğu söylenebilir. 
Maroof'un (2012) da belirttiği gibi bir ölçüm aracının kavramsal olarak ilgili bir ölçüt ile arasında anlamlı bir ilişkinin olması beklenmektedir.

Güvenirlik değerleri incelendiğinde ise hem faktör bazında hem de boyut bazında güvenirlik değerlerinin kabul edilebilir sınırlar içerisinde olduğu söylenebilir (George \& Mallery 2010; Kayış, 2005 akt. Erol 2018; Nunnally 1978; Özdamar 2004 akt. Erol 2018).

Uyarlanan ölçeğin faktörleri arasında anlamlı korelasyonlar olduğu görülmektedir. N faktörü ile $\mathrm{E}, \mathrm{A}, \mathrm{C}$ ve $\mathrm{O}$ faktörleri arasında olumsuz ve anlamlı bir ilişki tespit edilmişken diğer faktörlerin birbirleri ile arasında olumlu ve anlamlı ilişkiler saptanmıştır. Benzer bulgular, daha önce farklı kişilik ölçüm araçlarıyla incelemede bulunan pek çok araştırmacı tarafindan tespit edilmiştir (örn. Bulut 2017; Ulu \& Bulut 2017; Yıldız \& Bulut 2017).

Yukarıda görüldüğü gibi, orijinal ölçek ve uyarlama ölçek incelendiğinde, genel anlamda faktör ve boyut bazında farklı dağılımların olduğu görülmektedir. Bunun bir nedeni, orijinal ölçeğin ve uyarlama ölçeğin uygulandığı kültürler arasındaki farklılıklar olabilir. Orijinal ölçeğin geliştirildiği bireyci kültürün, uyarlama yapılan toplulukçu kültürden pek çok yönden farklı olduğu daha önce yapılan çalışmalarla gösterilmiştir. Bireyci kültürlerde yaşayan kişiler bağımsızlığa ve kendi çıkarlarına önem verirken toplulukçu kültürlerde yaşayanlar için grup ve grubun çıkarları ön plana çıkmaktadır (Hofstede 1980; Kağıtçıbaşı 2012; Markus \& Kitayama 1991). Bununla birlikte, kişiliği oluşturan ögeler açısından değerlendirdiğimizde sözü edilen bu kültürel farklılıklar, kimlik gelişimi açısından toplumsal ve ekolojik çevrenin önemine vurgu yapmaktadır. Ayrıca benlik, karakter ve mizaç gelişimindeki toplumsal ve bireysel ya da çevresel ve biyolojik/genetik gelişim faktörlerini de şüphesiz göz ardı etmek olası değildir. Birey-toplum etkileşimi kişilik gelişimin tüm yönleriyle yakından ilişkilidir ve döngüseldir. Yani toplumun mizaç ve karakteri, o toplumu meydana getiren bireylerin mizaç ve karakterlerinin genel bir yansıması olarak değerlendirilebilir. Birey ve topluluğun, her birinin diğerini gerektiren ve birbirleriyle ilişkili iki kavram olduğunu ileri süren Wundt, "Halkların Psikolojisi (Völkerpsychologie)" adlı eserinde, bireysel zihin ile kolektif zihin arasındaki ilişkiyi açıklarken "zihni bütün içsel deneyimlerin bir toplamı olarak tanımlamakta, pek çok deneyimin, özellikle de dilin ve mitsel imgelerin topluluk içinde paylaşıldiğına" işaret etmektedir. Ona göre, bu gelişim sırasında bireysel ve kolektif zihinler birbirlerini karşl1ıklı olarak etkilerler ve kolektif zihindeki değişiklikler bireysel zihindekilerle aynı derecede yasalara tabidir (Jahoda 2011, 164). Kültürel ya da kültürlerarası psikoloji çalışmalarının bir taraftan birey-toplum etkileşimini incelerken öte taraftan da bireyin tutumlarını ya da psikolojik analiz gerektirecek başka durumları kültürel farklılıklar bakımından incelemeyi amaç edindiği bilinmektedir. Özellikle farklı ülkelerde ve farklı zamanlarda gerçekleştirilen araştırmalar, katılımcıların çeşitli milletleri (Almanları, Türkleri, İngilizleri, Amerikalıları vb.) karakter, mizaç yani kişilik özellikleri ile değerlendirdiklerini, bireysel psikolojilerinin yanı sıra kendi kültür kodlarıyla hareket ettiklerini de göstermektedir (Kağıtçıbaşı 2013).

Benlik gelişimi açısından ele alındığında, bireyin kendisine ilişkin doğru ya da yanlış her türlü düşünce, değerlendirme ve farkındalık düzeyleri üzerine aile, eğitimin niteliği, kültür, diğer insanlar, ülkenin siyasi yapısına kadar birçok faktör şekillendirici olabilmektedir. Bu nedenle, kişiliğin çevre merkezli gelişimi kaçınılmaz olarak envanterin maddelerinin algılanmasını bir şekilde etkileyebilmektedir. Özetle, tüm bu tartışmalar aslında psikometrik ölçüm araçlarının evrensel olup olmayacağı tartışmaları çerçevesinde hep tartışılagelmiştir.

$\mathrm{Bu}$ ölçek, faktörlerden ve boyutlardan oluşması açısından ülkemizde kullanılan pek çok kişilik ölçüm aracından farklılaşmaktadır. Kişiliği boyut bazında incelemeye izin vermesi, bu alanda daha fazla bilgi sahibi olmamıza yardımcı olmaktadır. Detaylı bir kişilik profili çıkarmamız 
bu konuyu derinlemesine incelememiz açısından ufuk açıcıdır. Dolayısıyla bu ölçeğin kişiliği beş faktör ve 19 boyutta analiz etmeye imkân tanımasının hem kişilik gelişimine hem de kişiliğin değişken olarak kullanıldığı araştırmalarda ulaşılacak bulguların analiz ve yorumlarının detaylandırılmasına katkı sağlayacağı umulmaktadır.

Özetle, yukarıda verilen geçerlik ve güvenirlik analizleri sonucunda B5FKE'nin geçerli ve güvenilir bir ölçüm aracı olarak ülkemizde kullanılabileceği sonucuna ulaşılmıştır.

$\mathrm{Bu}$ çalışmanın bazı sınırlılıkları bulunmaktadır. Öncelikle, örneklem grubunun üniversite öğrencilerinden oluşması çalışmanın sınırlılı̆̆ larda ölçeğin farklı örneklem gruplarında test edilerek geçerlik ve güvenirlik çalışmalarının yapılması önerilmektedir. Diğer bir sınırlılık ise bu çalışmada ölçüt geçerliği için tek bir ölçeğin kullanılmış olmasıdır. Bu ölçeğe ek olarak kişilikle ilişkili olabilecek farklı bir ölçek daha kullanılabilirdi. Güvenirlik analizi kapsamında ise iç tutarlılık ve iki yarım güvenirlik katsayısına ek olarak ileride yapılacak olan çalışmalarda test tekrar test güvenirlik yönteminin kullanılması önerilmektedir. 


\section{KAYNAKÇA}

Atak H. (2013). “On-Maddeli Kişilik Ölçeği'nin Türk Kültürü'ne Uyarlanması”. Nöropsikiyatri Arşivi 50 (2013) 312-319.

Bacanlı H., İlhan T. \& Aslan S. (2009). "Beş Faktör Kuramına Dayalı Bir Kişilik Ölçeğinin Geliştirilmesi: Sıfatlara Dayalı Kişilik Testi”. Türk Eğitim Bilimleri Dergisi 7/2 (2009) 261-279.

Benet-Martinez V. \& John O. P. (1998). "Los Cinco Grandes Across Cultures an Ethnic Groups: Multitrait Method Analysis of the Big Five in Spanish and English”. Journal of Personality and Social Psychology 75 (1998) 729-750.

Bulut M. B. (2017). “Akademisyenlerin Örgütsel Bağlılıkları, Kişilik Özellikleri ve Tükenmişlik Düzeyleri Arasındaki İlişkiler”. Uluslararası Sosyal Araştırmalar Dergisi 10/50 (2017) 62-370.

Burger J. M. (2006). Kişilik. İstanbul 2006.

Byrne B. (2010). Structural Equation Modelling with AMOS: Basic Concepts, Application, and Programming. New York 2010.

Costa P. T. \& Widiger T. A. (2002). "Introduction: Personality Disorders and the Five Factor Model of Personality”. Eds. P. T. Costa \& T. A. Widiger, Personality Disorders and the Five Factor Model of Personality (2002) 3-14. Washington.

Demirgöz-Bal M. \& Hotun-Şahin N. (2011). "Cervantes Kişilik Ölçeğinin Türkçeye Uyarlanması: Geçerlik ve Güvenirlik Çalışması”. Hemşirelikte Eğitim ve Araştırma Dergisi 8/1 (2011) 39-45.

Erol E. (2018). Çocuk Depresif Semptom Ölçeği Geliştirme Çalışması. Doktora Tezi. İstanbul Arel Üniversitesi, İstanbul 2018.

Feist J. \& Feist G. J. (2009). Theories of Personality. New York 2009.

George D. \& Mallery M. (2010). SPSS for windows Step by Step: A Simple Guide and Reference. Boston 2010.

Goldberg L. R., John O. P., Kaiser H., Lanning K. \& Peabody D. (1990). “An Alternative Description of Personality”. The Big-Five Factor Structure 59/6 (1990) 1216-1229.

Hofstede G. (1980). Culture's Consequences: International Differences in Work-Related Values. Beverly Hills 1980.

Horzum M. B., Ayas T. \& Padır M. A. (2017). "Beş Faktör Kişilik Ölçeğinin Türk Kültürüne Uyarlanması". Sakarya University Journal of Education 7/2 (2017) 398-408.

Jahoda G. (2011). Sosyal Psikoloji Tarihi. İstanbul 2011.

Kağıtçıbaşı Ç. (2013). Günümüzde İnsan ve İnsanlar. İstanbul 2013.

Kağıtçıbaşı Ç. (2012). Self, Family, and Human Development. İstanbul 2012.

Karaman N. G., Dogan T. \& Coban A. E. (2010). "A Study to Adapt the Big Five İnventory to Turkish”. Procedia Social and Behavioral Science 2 (2010) 2357-2359.

Karancı A. N., Dirik G. \& Yorulmaz O.. "Eysenck Kişilik Anketi - Gözden Geçirilmiş Kısaltılmış Formunun (EKA-GGK) Türkiye'de Geçerlik ve Güvenilirlik Çalışması”. Türk Psikiyatri Dergisi 18/3 (2007) 254-261.

Konuk E. (1996). The Development of the Turkish Form Test-Retest Reliability and Validity Studies of the Sixteen Personality Factor Questionnaire (16 pf). Master Thesis. Boğaziçi Üniversitesi, Sosyal Bilimler Enstitüsü, İstanbul 1996.

Leech N. L., Barrett K. C. \& Morgan G. A. (2005). SPSS for Intermediate Statistics Use and Interpretation. Mahwah 2005.

Markus H. R. ve Kitayama S. (1991). "Culture and the Self: Implications for Cognition, Emotion, and Motivation”. Psychological Review 98 (1991) 224-253.

Maroof D. A. (2012). Statistical Methods in Neuropsychology. Common Procedures Made Comprehensible. US 2012.

McCrae R. R. \& Costa P. T. (1987). "Validation of the Five-Factor Model of Personality Across Instruments and Observers”. Journal of Personality and Social Psychology 52/1 (1987) 81-90.

McCrae R. R. \& John O. P. (1992). “An Introduction to the Five Factor Model and its Applications”. 
Journal of Personality 60 (1992) 175-215.

McGraw-Hill-Education (Ed.) (2016). Aklımın Aklı: Psikoloji. Ankara 2016.

Morsünbül Ü. (2014). "Hızlı Büyük Beşli Kişilik Testi Türkçe Versiyonu Geçerlilik ve Güvenirlik Çalışması”. Düşünen Adam the Journal of Psychiatry and Neurological Sciences 27/4 (2014) 316-322.

Nunnally J. C. (1978). Psychometric Theory. New York 1978.

Özgüven İ. E. (1992). Hacettepe Kişilik Envanteri El Kitabı. Ankara 1992.

Savaşır I. (1978). “Minnesota Çok Yönlü Kişilik Envanterinin Türkçeye Uyarlanışı ve Standardizasyon Projesi”. Türk Psikoloji Dergisi 1/1 (1978) 18-24.

Savran C. (1993). Slfat Listesi'nin (Adjective Check List) Türkiye Koşullarına Uygun Dilsel Eşdeğerlilik, Geçerlik, Güvenirlik ve Norm Çalışması ve Örnek Bir Uygulama. Yüksek Lisans Tezi. Marmara Üniversitesi, Sosyal Bilimler Enstitüsü, İstanbul 1993.

Scherer R. F., Wiebe F. A., Luther D. C. \& Adams J. S. (1988). "Dimensionality of Coping: Factor Stability Using the Ways of Coping Questionnaire”. Psychological Reports 62 (1988) 763-770.

Schermelleh-Engel K., Moosbrugger H. \& Müller H. (2003). "Evaluating the Fit of Structural Equation Models: Tests of Significance and Descriptive Goodness-of-fit Measures”. Methods of Psychological Research Online 8/2 (2003) 23-74.

Somer O., Korkmaz M. \& Tatar A. (2000). “Beş Faktör Kişilik Envanteri’nin Geliştirilmesi-I: Ölçek ve Alt Ölçeklerin Oluşturulması”. Türk Psikoloji Dergisi 17/49 (2000) 21-33.

Somer O., Korkmaz M. \& Tatar A. (2004). Kuramdan Uygulamaya Beş Faktör Kişilik Modeli ve Beş Faktör Kişilik Envanteri (5FKE). İzmir 2004.

Specht J., Bleidorn W., Denissen J. J. A., Hennecke M., Hutteman R., Kandler C., Luhmann M., Orth U., Reitz A. K. \& Zimmermann J. (2014). "What Drives Adult Personality Development? A Comparison of Theoretical Perspectives and Empirical Evidence”. European Journal of Personality 28 (2014) 216-230.

Subaş A. \& Çetin M. (2017). "Enneagram Kişilik Ölçeğinin Geliştirilmesi: Güvenirlik ve Geçerlilik Çalışması”. Sosyal Bilimler Dergisi 4/11 (2017) 160-181.

Sümer N. \& Sümer H. C. (2005). Beş Faktör Kişilik Özellikleri Ölçeği. (Yayımlanmamış Çalışma).

Tabachnick B. G. \& Fidell L. S. (2001). Using Multivariate Statistics. MA 2001.

Tatar A. (2016). "Beş Faktör Kişilik Ölçeğinin Kısa Formunun Geliştirilmesi”. Anadolu Psikiyatri Dergisi 17 (2016) 14-23.

Tatar A. (2017). "Büyük Beş-50 Kişilik Testinin Türkçeye Çevirisi ve Beş Faktör Kişilik Envanteri Kısa Formu ile Karşılaştırılması”. Anadolu Psikiyatri Dergisi 18/1 (2017) 51-61.

Thompson B. (2004). Exploratory and Confirmatory Factor Analysis: Understanding Concepts and Applications. Washington 2004.

Ulu M. \& Bulut M. B. (2017). “Üniversite Öğrencilerinin Kişilik Özelliklerinin HEXACO ile Ölçülmesi”. Bilimname 34/2 (2017) 443-462.

Wasti S. A., Lee K., Ashton M. C. \& Somer O. (2008). "Six Turkish Personality Factors and the HEXACO Model of Personality Structure”. Journal of Cross-Cultural Psychology 39/6 (2008) 665684.

Watson D., Nus E. \& Wu K. D. (2017). "Development and Validation of the Faceted Inventory of the Five-Factor Model (FI-FFM)”. Assessment (2017) 1-28.

Yıldız M. \& Bulut M. B. (2017). “Ölüm Kaygısı ile Kişilik Özellikleri Arasındaki İlişkiler”. Turkish Studies 12/13 (2017) 659-676. 